\title{
Hydrodeoxygenation of phenol on bifunctional Ni-based catalysts: Effects of Mo promotion and support
}

\author{
E. Kordouli ${ }^{a, *}$, B. Pawelec ${ }^{b *}$, C. Kordulis ${ }^{a, c, d}$, A. Lycourghiotis ${ }^{a, d}$, J.L.G. Fierro ${ }^{b}$ \\ ${ }^{a}$ Department of Chemistry, University of Patras, Patras, Greece \\ $b$ \\ Instituto de Catalísis y Petroleoquímica, CSIC, Marie Curie 2, Cantoblanco, 28049 \\ Madrid, Spain \\ ${ }^{c}$ Foundation of Research and Technology-Institute of Chemical Engineering Science \\ (FORTH/ICE-HT) Stadiou Str. Platani, P.O. Box 1414, GR-26500, Patras, Greece \\ ${ }^{d}$ School of Science and Technology, Hellenic Open University, Tsamadou 13-15, GR- \\ 26222, Patras, Greece
}

*To whom all correspondence should be addressed

E-mail: ekordouli@upatras.gr (E.K.);bgarcia@icp.csic.es (B.P.)

\begin{abstract}
Hydrodeoxygenation (HDO) of phenol dissolved in decalin was studied over partially reduced $\mathrm{Ni}$ and Mo-Ni catalysts supported on alumina and amorphous silica alumina (ASA) in the context of the O-removal from bio-liquids. The activity test was carried out in a flow reactor at $310^{\circ} \mathrm{C}$ and total hydrogen pressure of $3 \mathrm{MPa}$. The catalyst samples were characterized by several physico-chemical techniques $\left(\mathrm{S}_{\mathrm{BET}}, \mathrm{H}_{2}\right.$-TPR, HRTEM, DRIFT spectroscopy of adsorbed $\mathrm{CO}$ and $\mathrm{NH}_{3}$, Raman spectroscopy, XPS, SEM-EDS and HRTEM) in order to obtain catalyst activity-structure correlation. After $4 \mathrm{~h}$ on stream, the partially reduced Mo-Ni/ASA catalyst displayed the highest activity in the HDO of phenol, which was linked with its highest Ni dispersion, the Mo promoting action and largest acidity. The partially reduced Mo-Ni/ASA catalyst displayed 2 times higher yield of $\mathrm{O}$-free products than a commercial $\mathrm{NiMoP}(\mathrm{S}) / \mathrm{Al}_{2} \mathrm{O}_{3}$ catalyst activated by sulfidation. The role of metals and metal oxides species in HDO reaction has been discussed.
\end{abstract}

Keywords: Phenol hydrodeoxygenation; Ni catalyst; Mo promoter; alumina; amorphous silica-alumina

\section{Introduction}

Biomass is a renewable alternative to fossil raw materials for the production of liquid fuels and chemicals. However, the biofuel liquid precursors obtained from biomass fast pyrolysis present high content of oxygen-containing compounds which contribute to lowering of its quality. Thus, the removal of oxygen is a challenge for meeting the specification of fuels in terms of viscosity, volatility, corrosiveness, miscibility and stability [1-3]. In order to improve the bio-oils characteristics, in the existing petroleum refining infrastructure, traditional hydrotreatment process can be employed targeting mainly to hydrodeoxygenation (HDO) [1]. At the beginning of 21th century, Furimsky has concluded that breakthroughs in the catalyst development may be required to make this biomass-derived fuels more attractive [1]. 
Past efforts for HDO catalyst development were focused on alumina supported hydroprocessing catalysts, intensively used in petroleum refining for several decades and therefore little attention has been paid to development of novel catalysts. Thus, the catalysts often studied for $\mathrm{HDO}$ were sulfided $\mathrm{CoMo} / \gamma-\mathrm{Al}_{2} \mathrm{O}_{3}$ and $\mathrm{NiMo} / \gamma-\mathrm{Al}_{2} \mathrm{O}_{3}$ systems [1-3]. Unfortunately, in the absence of a sulfiding agent, the sulfided catalysts are deactivated quickly in HDO reaction and the selectivity to different hydrocarbons changed with time on-stream due to oxidation of the active phases [4]. Thus, great efforts have been devoted to enhance the stability of these catalysts substituting sulfided active phases by metallic, phosphide, carbide and nitride ones [5-9]. Noble metal catalysts offer exciting potential [4-7,10,11 and references within] because under mild conditions they are especially effective in the activation of molecular hydrogen. However, such catalysts are difficultly adopted by the industry especially due to their high cost. Recent laboratory and commercial developments in the field of catalytic hydroprocessing of biomassderived oils are presented in a few excellent reviews. [10-14]

Currently, $\mathrm{Al}_{2} \mathrm{O}_{3}$ was most widely used as the support in traditional hydroprocessing catalysts. However, there is some confusion concerning its use as support for HDO catalysts. On the one hand, reduced NiMo catalysts supported on $\gamma$-alumina proved to be more active than their counterparts supported on titania [15]. On the other hand, alumina was claimed not to be suitable support for bio-oil upgrading because of its low tolerance to water contained into bio-oil [16]. Alumina supports have been also reported to produce large amount of coke due to weak Lewis type acidic sites on their surfaces $[17,18]$. In addition, the metallic catalysts supported on alumina exhibit strong metal-support interactions, which result to undesired solid-state reactions of molybdenum and mainly nickel oxides with the alumina surface. The preparation method followed plays a key role on the aforementioned interactions. Indeed, there is some literature evidence that alumina prepared by sol-gel method has a more stable support structure and nickel catalysts exhibit higher nickel dispersion than $\mathrm{Ni} / \mathrm{Al}_{2} \mathrm{O}_{3}$ catalysts made by impregnation on $\gamma-\mathrm{Al}_{2} \mathrm{O}_{3}$, resulting in higher activity and resistance to carbon deposition [19-21].

Amorphous silica-alumina (ASA) is considered a good candidate for supporting Ni catalysts because it exhibits the advantage of low metal-support interactions [22]. However, minimizing the metal-support interactions in catalysts by using ASA as carriers might to lead to poor dispersion of the active phases, which is known to be the principal reason for lower HDO activity. This problem could be alleviated by using a suitable method for the catalyst preparation $[13,23,24]$.

Nickel-based catalysts are known to exhibit exceptionally good hydrogenation /dehydrogenation [25-27], hydrogenolysis [28,29] and hydrodeoxygenation [30,31] properties. It has been reported that the surface defects in metallic Ni serve as capture traps for surface hydrogen which reduces the activation energy of hydrogen dissociation, and the largely increased surface defects can be achieved by decreasing the supported $\mathrm{Ni}$ particles size into nano-scale with a simultaneously increased Ni dispersion [32]. Moreover, the rate of coke formation has been found to be proportional to the particle 
size of $\mathrm{Ni}$, and below a critical Ni particle size $(\mathrm{d}<2 \mathrm{~nm})$, the coke formation becomes dramatically slow [33].

Concerning the active phase, the role of the different $\mathrm{Ni}$ phases in HDO reaction $\left(\mathrm{Ni}^{0}\right.$, $\mathrm{NiO}_{x}, \mathrm{Ni}$ spinel etc.) is still not well understood. This is probably because, in general, the $\mathrm{Ni}$ is used as promoter of $\mathrm{Mo}(\mathrm{W})$-based HDO catalysts [34]. The reverse situation of the Mo promotion of Ni-based catalysts is scarcely reported [35]. Interestingly, the effect of addition of $\mathrm{Mo}$ to $\mathrm{Ni} / \mathrm{Al}_{2} \mathrm{O}_{3}$ catalysts for methane steam reforming was recently investigated by Maluf and Assaf [35]. It was found evidence of electrons transfer form $\mathrm{MoOx}$ species to $\mathrm{Ni}$, leading to an increase in the electron density of metallic $\mathrm{Ni}$, and hence, in the catalytic activity. Our group has recently studied the promoting action of $\mathrm{Mo}$ in $\mathrm{Ni} / \mathrm{Al}_{2} \mathrm{O}_{3}$ catalysts for hydrodeoxygenation of natural triglycerides [36,37]. It has been concluded that $\mathrm{Ni} / \mathrm{Al}_{2} \mathrm{O}_{3}$ catalysts with high $\mathrm{Ni}$ content (in the range of $60 \mathrm{wt} \%$ ) are quite promising for hydrodeoxygenation of vegetable oils [38] while promotion by Mo adopting a $\frac{N i}{N i+M o}$ synergistic atomic ratio approaching 0.9 enhances the catalytic performance of the corresponding catalyst [37].

Taking into account that the phenolic compounds represent approximately a quarter part of the oxygen-containing organic compounds present in the bio-liquids, this work was undertaken with the objective to study the effect of Mo addition to Ni catalysts supported on $\mathrm{Al}_{2} \mathrm{O}_{3}(\mathrm{Al})$ and silica-alumina (ASA) on their catalytic response in the HDO of phenol reaction. The aforementioned $\frac{\mathrm{Ni}}{\mathrm{Ni}}$ synergistic atomic ratio has been adopted for the catalysts formulation. The liquid feed consists with 2 wt.\% of phenol dissolved in decaline.

\section{Experimental}

\subsection{Catalyst preparation}

$\mathrm{Ni} / \mathrm{Al}_{2} \mathrm{O}_{3}(\mathrm{Ni} / \mathrm{Al})$ and $\mathrm{Mo}-\mathrm{Ni} / \mathrm{Al}_{2} \mathrm{O}_{3}(\mathrm{Mo}-\mathrm{Ni} / \mathrm{Al})$ catalysts were prepared by hydrothermal co-precipitation. Carefully weighted amounts of $\mathrm{Ni}\left(\mathrm{NO}_{3}\right)_{2} \cdot 6 \mathrm{H}_{2} \mathrm{O}$ (Merck, kGaA), $\mathrm{Al}\left(\mathrm{NO}_{3}\right)_{3} \cdot 9 \mathrm{H}_{2} \mathrm{O}$ (Alfa Aesar) and $\left(\mathrm{NH}_{4}\right)_{6} \mathrm{Mo}_{7} \mathrm{O}_{24} \cdot 4 \mathrm{H}_{2} \mathrm{O}$ (Alfa Aesar) in the case of bimetallic catalyst were dissolved in $\mathrm{NH}_{4} \mathrm{OH}$ aqueous solution in a spherical bottle with reflux condenser and magnetic stirrer immersed in a heated oil bath $\left(100^{\circ} \mathrm{C}\right)$. After $6 \mathrm{~h}$ under reflux the suspension obtained was cooled down to ambient temperature and the solid formed was filtered, washed with 3 -distilled water and dried at $110^{\circ} \mathrm{C}$ overnight in air. The dried samples were decomposed in a stream of $\mathrm{He}(30 \mathrm{~mL}(\mathrm{STP}) / \mathrm{min})$ at $400{ }^{\circ} \mathrm{C}\left(2{ }^{\circ} \mathrm{C} / \mathrm{min}\right)$ for $2.5 \mathrm{~h}$ to obtain catalyst precursors. A similar procedure was followed for the preparation of $\mathrm{Ni} / \mathrm{SiO}_{2}$ $\mathrm{Al}_{2} \mathrm{O}_{3}(\mathrm{Ni} / \mathrm{ASA})$ and $\mathrm{Mo}-\mathrm{Ni} / \mathrm{SiO}_{2}-\mathrm{Al}_{2} \mathrm{O}_{3}(\mathrm{Mo}-\mathrm{Ni} / \mathrm{ASA})$ catalyst. A commercially available support, amorphous $\mathrm{SiO}_{2}-\mathrm{Al}_{2} \mathrm{O}_{3}$ (ASA / SMR-5-473, Grace Davison Chemical) containing $28 \mathrm{wt} . \%$ of alumina was employed for the preparation of latter catalysts. Prior to catalyst preparation, ASA material was calcined at $500{ }^{\circ} \mathrm{C}$ for $3 \mathrm{~h}$. In this case depositionprecipitation of the active phase(s) precursors was achieved on ASA support under the conditions reported above for the co-precipitated samples. Final catalysts were obtained by 
in situ reduction of catalyst precursors at $450{ }^{\circ} \mathrm{C}$ for $2 \mathrm{~h}$ in a stream of $\mathrm{H}_{2}(50 \mathrm{~mL}(\mathrm{STP}) / \mathrm{min})$. Samples prepared for characterization purposes underwent the same reduction ex situ followed by passivation, feeding the reactor at room temperature with $1 \mathrm{v} / \mathrm{v} \% \mathrm{O} 2$ in $\mathrm{Ar}$ stream $(20 \mathrm{~mL}(\mathrm{STP}) / \mathrm{min})$ for $0.5 \mathrm{~h}$.

\subsection{Catalyst composition}

Energy-dispersive X-ray spectroscopic (EDS) analysis of the final catalysts performed on a Scanning Electron Microscope (SEMJEOL JSM6300) equipped with an Energy Dispersive Spectrometry accessory. The chemical composition of the samples was determined using natural and synthetic standards and $20 \mathrm{kV}$ accelerating voltage with $10 \mathrm{nA}$ beam current. Microanalysis was performed on gold coated samples. The sample powders were mounted directly on the sample holder. The morphology of the samples was also examined using the same microscope.

\section{3. $N_{2}$ adsorption-desorption isotherms of the catalysts}

The textural properties of the fresh reduced samples were determined from the adsorption-desorption isotherms of nitrogen at $-196^{\circ} \mathrm{C}$, recorded with a Micromeritics TriStar 3000 apparatus. Prior to the experiments, the samples were degassed at $270{ }^{\circ} \mathrm{C}$ in vacuum for $5 \mathrm{~h}$. The volume of the adsorbed $\mathrm{N}_{2}$ was normalized to the standard temperature and pressure. $\mathrm{N}_{2}$ adsorption isotherms were measured at relative pressures $\left(P / P_{0}\right.$, where $P$ is the actual pressure of $\mathrm{N}_{2}$ and $P_{0}$ is the saturation pressure of $\mathrm{N}_{2}$ at -196 ${ }^{\circ} \mathrm{C}$ ) in the range of 0.0001 to 0.99 . The adsorption data were then used to determine BET surface area $\left(0.005<P / P_{0}<0.25\right)$, total pore volume at $P / P_{0} \approx 0.99$, and pore size distributions (PSDs) using the 3-D model [39] for slit shaped micropores (pore width $<$ $2.0 \mathrm{~nm}$ ) and the BJH model [40] for mesopores (2.0 $\mathrm{nm}<$ pore width $<50.0 \mathrm{~nm}$ ). In order to avoid the tensile strength (TSE) artifact, the pore size distribution (PSD) curves were calculated by applying the BET method to the adsorption branches of the $\mathrm{N}_{2}$ isotherms.

\subsection{X-ray diffraction (XRD)}

The fresh reduced samples were characterized by powder X-ray diffractometry according to the step-scanning procedure (step size $0.04^{\circ} ; 20 \mathrm{~s}$ ) with a computerized Seifert 3000 diffractometer, using Ni-filtered $\mathrm{CuK} \alpha(\lambda=0.15406 \mathrm{~nm})$ radiation and a PW $2200 \mathrm{Bragg}$ Brentano $\theta / 2 \theta$ goniometer equipped with a bent graphite monochromator and an automatic slit. The assignment of the various crystalline phases were based on the JPDS powder diffraction file cards. The metal particle sizes were calculated from the line broadening of the most intense peak using the Debye-Scherrer equation.

\subsection{Raman spectroscopy}

Raman spectra were recorded with a Renishaw in Via Raman Microscope spectrometer equipped with a laser beam emitting at $785 \mathrm{~nm}$, at $300 \mathrm{~mW}$ output power. The photons scattered by the sample were dispersed by a 1200 lines/mm grating monochromator and simultaneously collected on a CCD camera; the collection optic was set at $50 \times$ objective. The spectral resolution was of $1 \mathrm{~cm}^{-1}$. 


\subsection{Temperature-programmed reduction $\left(\mathrm{H}_{2}-\mathrm{TPR}\right)$}

The reduction behavior of the just He-decomposed samples was studied by temperatureprogrammed reduction ( $\mathrm{H}_{2}$-TPR) using a Micromeritics TPR/TPD 2900 instrument. The sample (ca. $40 \mathrm{mg}$ ) diluted by quartz powder was put in a quartz reactor and reduced in flowing gas containing $10 \%$ vol. $\mathrm{H}_{2}$ in $\mathrm{Ar}$ at a total flow rate of $50 \mathrm{~mL}(\mathrm{STP}) / \mathrm{min}$ by increasing linearly the temperature $\left(15^{\circ} \mathrm{C} / \mathrm{min}\right)$ up to a final temperature of $900{ }^{\circ} \mathrm{C}$.

\subsection{High Resolution Transmission Electron Spectroscopy (HRTEM) measurements}

HRTEM microscopy studies were carried out using a JEM 2100F microscope operating with a $200 \mathrm{kV}$ accelerating voltage and fitted with a INCA X-sight (Oxford Instruments) energy dispersive X-ray microanalysis (EDX) system to verify semi-quantitative composition of supported phases. The pre-reduced catalysts $\left(5 \% \mathrm{H}_{2} / \mathrm{He}, 300{ }^{\circ} \mathrm{C}, 1 \mathrm{~h}\right)$ were crushed and dispersed ultrasonically in acetone at room temperature and then spread onto a lacey carbon-coated $\mathrm{Cu}$ grid. Particle size distribution was evaluated by statistical treatment of several micrographs taken from the same sample. The average particle size was estimated using the equation $d=\sum n_{i} \cdot d_{i} / \sum n_{i}$, where $n_{i}$ is the number of particles with diameter $\mathrm{d}_{\mathrm{i}}$ and $\sum \mathrm{n}_{\mathrm{i}}$ is the number of particles used to build the size distribution.

\subsection{X-ray photoelectron spectroscopy (XPS)}

Photoelectron spectra of fresh reduced and spent catalysts were recorded on a VG Escalab 200R electron spectrometer equipped with a hemispherical electron analyzer, using a $\operatorname{MgK} \alpha\left(h v=1253.6 \mathrm{eV}, 1 \mathrm{eV}=1.603 \times 10^{-19} \mathrm{~J}\right) \mathrm{X}$-ray source. After outgassing at $10^{-6}$ mbar, the samples were transferred to the ion-pumped analysis chamber, in which the residual pressure was kept below $4 \times 10^{-9}$ mbar during data acquisition. The binding energy (BE) of the $\mathrm{C} 1 \mathrm{~s}$ peak at $284.5 \mathrm{eV}$ was taken as an internal standard. The accuracy of the BE values was $\pm 0.1 \mathrm{eV}$. Peak intensities were estimated by calculating the integral of each peak after subtracting an S-shaped background and fitting the experimental peak to a mix of Lorentzian/Gaussian (10L/90G) lines. Atomic surface contents were estimated from the areas of the peaks, corrected using the corresponding sensitivity factors [41].

\subsection{DRIFTS of CO adsorption}

To evaluate the effect of support and Mo addition on the type and amount of different species, the fresh reduced samples were studied by DRIFT spectroscopy of adsorbed CO. Diffuse reflectance spectra were collected on a Nicolet 510 FTIR spectrophotometer, equipped with a diffuse reflectance unit and a reaction Harrick cell, at a spectral resolution of $4 \mathrm{~cm}^{-1}$ using a total 500 scans per spectrum. The background of the sample was recorded prior to $\mathrm{CO}$ adsorption studies. Spectra were recorded after a period of about 10 min, which was followed by purging of the cell for $0,5 \mathrm{~h}$ with Ar to remove gaseous $\mathrm{CO}$.

\subsection{DRIFTS of $\mathrm{NH}_{3}$ adsorption}

Diffuse Reflectance Infrared Fourier Transform Spectroscopy of adsorbed $\mathrm{NH}_{3}$ was employed to investigate and compare acidity of the in situ $\mathrm{H}_{2}$-reduced catalysts. Spectra were collected on the aforementioned Nicolet 510 FTIR spectrophotometer working at a resolution of $4 \mathrm{~cm}^{-1}$ (500 scans), now utilizing a Harrick HVC-DRP cell that allows in situ treatments with different gases. After sample reduction with pure $\mathrm{H}_{2}$ at $450{ }^{\circ} \mathrm{C}$ for 30 
min, the temperature was cooled down in He to $120{ }^{\circ} \mathrm{C}$. Prior to spectrum recording, the sample was subjected to the $5 \mathrm{~mol} \% \mathrm{NH}_{3} / \mathrm{He}$ analysis gas (Air Liquide) for $45 \mathrm{~min}$. The temperature $120{ }^{\circ} \mathrm{C}$ was chosen for $\mathrm{NH}_{3}$ adsorption in order to avoid physical adsorption of this molecule.

\subsection{Activity tests}

Prior to activity tests, the Ni-based catalysts were activated by in situ reduction with pure $\mathrm{H}_{2}\left(50 \mathrm{~mL}(\mathrm{STP}) \mathrm{min}^{-1}\right)$ at $450{ }^{\circ} \mathrm{C}$ for $2 \mathrm{~h}$. The hydrodeoxygenation of phenol was performed in a high-pressure laboratory-scale set-up equipped with a down-flow fixed bed catalytic reactor. For the activity test, $0.1 \mathrm{~g}$ of the catalyst with particle size $0.25-0.30$ $\mathrm{mm}$ was used. Prior to the run, the pressure and temperature in the reactor were increased up to $3.0 \mathrm{MPa}$ and $310^{\circ} \mathrm{C}$, respectively. The catalyst activity was evaluated as a function of time-on-stream: the weight hourly space velocity (WHSV) was of $107.5 \mathrm{~h}^{-1}$ and total reaction time was $4 \mathrm{~h}$. The liquid feed consist with $2 \mathrm{wt} . \%$ of phenol dissolved in decaline. Decaline was chosen as solvent with the objective to obtain additional $\mathrm{H}_{2}$ supply for phenol HDO transformation. The liquid feed was injected by a high-pressure HPLC Knauer pump into a hydrogen stream $\left(50 \mathrm{~mL} \mathrm{~min}^{-1}\right)$. Each value of total phenol conversion was the average of three different analysis of the liquid product taken at each hour of reaction time.

Collected liquid samples were analyzed by a GC Agilent 6890 A provided with a FID detector and a HP-INNOwax column (Crosslinked Polyethylene Glycol; $30 \mathrm{~m}$ x $0.25 \mathrm{~mm}$ x $0.25 \mu \mathrm{m}$; split 300:1). In addition, the liquid effluents were analyzed by GC-MS (Shimadzu GM-MS QP2010) provided with a BPX5 column (50 m x $0.22 \mathrm{~mm}$ x 0.25 $\mu \mathrm{m})$. Products were identified and quantified by using standard compounds. The main products of phenol transformation were cyclohexane $(\mathrm{CH})$, cyclohexene (CHE), cyclohexanol $(\mathrm{CHO})$ and benzene $(\mathrm{B})$. Traces of the substituted cyclohexanes $\left(\mathrm{CH}-(\mathrm{R})_{\mathrm{x}}\right)$ and several other products from the dehydrogenation (tetralin), cracking and isomerization of decalin were identified also by GC-MS. With exception of tetralin, the products of decalin transformation were difficult to quantify. Thus, decalin conversion has been used as a rough estimate of in situ hydrogen production. The HDO catalyst performances were determined as phenol conversion and yield toward O-free products.

A commercial $\mathrm{NiMo} / \mathrm{Al}_{2} \mathrm{O}_{3}$ catalyst (HR-348 from Procatalyse; $\mathrm{S}_{\mathrm{BET}}=164 \mathrm{~m}^{2} \mathrm{~g}^{-1}$; and Mo, Ni and P loading of 10.7, 2.5, and $2.64 \mathrm{wt} . \%$, respectively) in its sulfided form was tested upon the same reaction conditions and was used as reference.

\section{Results and discussion}

\subsection{Catalyst characterization}

\subsubsection{Catalysts composition}

Table 1 involves the catalysts prepared and their composition determined by SEM-EDS analysis of the activated samples. The obtained values are very close to the nominal ones ( $\sim 60$ wt. $\%$ of deposited metals and $\sim 40$ wt. $\%$ of support). Moreover, the results of EDS 
analysis concerning the alumina content of the ASA support in the corresponding catalysts are in good agreement with the composition given by the company.

Table 1: Catalysts composition

\begin{tabular}{lcccc}
\hline Sample & Mo (wt.\%) & $\mathrm{Ni}$ (wt.\%) & $\mathrm{SiO}_{2}$ (wt.\%) & $\mathrm{Al}_{2} \mathrm{O}_{3}$ (wt.\%) \\
\hline $\mathrm{Ni} / \mathrm{Al}$ & - & 60.5 & - & 39.5 \\
$\mathrm{Ni} / \mathrm{ASA}$ & - & 59.0 & 28.9 & 12.1 \\
$\mathrm{Mo}-\mathrm{Ni} / \mathrm{Al}$ & 7.4 & 53.8 & - & 38.8 \\
$\mathrm{Mo-Ni} / \mathrm{ASA}$ & 6.4 & 46.6 & 33.0 & 14.0 \\
\hline
\end{tabular}

\subsubsection{Catalyst texture}

Textural properties of the $\mathrm{H}_{2}$ pre-treated catalysts are shown in Table 2. Catalysts with high specific surface areas $\left(\mathrm{S}_{\mathrm{BET}}\right)$ have been obtained in the most of cases independently of the preparation method used. Only in the case of $\mathrm{Ni} / \mathrm{Al}$ sample relatively low $\mathrm{S}_{\mathrm{BET}}$ value has been obtained inducing relatively low dispersion of Ni phase in this sample. This argument has been confirmed by XRD, TEM and XPS results (see below). All the samples exhibit similar total pore volume values in the range $0.39-0.49 \mathrm{~cm}^{3} \cdot \mathrm{g}^{-1}$. In contrast, great differences are observed in the mean pore diameter $(d)$ of the catalysts.

Table 2. Textural properties and Brønsted-to-Lewis acidities ratio of fresh reduced samples.

\begin{tabular}{|c|c|c|c|c|}
\hline Sample & $\mathrm{S}_{\mathrm{BET}}\left(\mathrm{m}^{2} \mathrm{~g}^{-1}\right)$ & $\mathrm{V}_{\text {total }}\left(\mathrm{cm}^{3} \cdot \mathrm{g}^{-1}\right)$ & $d(\mathrm{~nm})$ & ratio $\mathrm{B} / \mathrm{L}^{\mathrm{a}}$ \\
\hline ASA & 394 & 0.74 & 7.5 & - \\
\hline $\mathrm{Ni} / \mathrm{Al}$ & 159 & 0.47 & 12 & 0.33 \\
\hline $\mathrm{Ni} / \mathrm{ASA}$ & 233 & 0.39 & 4.3 & 0.68 \\
\hline Mo-Ni/Al & 200 & 0.49 & 8.9 & 0.44 \\
\hline Mo-Ni/ASA & 217 & 0.48 & 6.8 & 0.64 \\
\hline
\end{tabular}

The Ni/Al catalyst exhibits the highest $d$ value $(12 \mathrm{~nm})$ in agreement with the relatively low $\mathrm{S}_{\mathrm{BET}}$ value and the corresponding pore size distribution curve presented in Fig. 1(a). Inspection of this curve shows that $\mathrm{Ni} / \mathrm{Al}$ catalyst has a wide pore size distribution with two main maxima at about 14 and $87 \mathrm{~nm}$. Addition of Mo-phase provoked reduction of 
$d$ value from 12 to $8.9 \mathrm{~nm}$ followed by an increase of $\mathrm{S}_{\mathrm{BET}}$ and transformation of pore size distribution curve to a tri-modal one whose maxima are placed at about 2.3, 3.9 and $59.3 \mathrm{~nm}$. ASA supported samples are characterized by relatively small $d$ values (Ni/ASA: $4.3 \mathrm{~nm}, \mathrm{MoNi} / \mathrm{ASA}: 6.8 \mathrm{~nm}$ ), probably due to the mesoporous texture of the pre-existing support. Mo-Ni/ASA catalyst exhibited slightly higher $d$ value than that of Ni/ASA one in accordance with the slight decrease of $\mathrm{S}_{\mathrm{BET}}$ and the pore size distribution curves presented in Fig. 1(b).
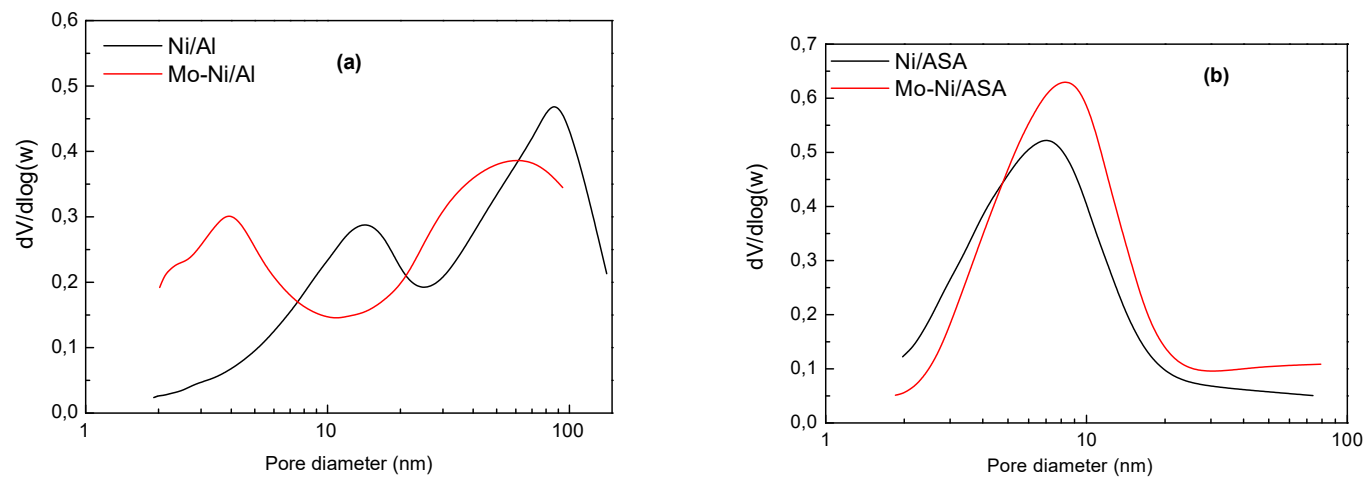

Figure 1. Pore size distribution curves of $\mathrm{Ni} / \mathrm{Al}$ and $\mathrm{Mo}-\mathrm{Ni} / \mathrm{Al}$ (a) as well as $\mathrm{Ni} / \mathrm{ASA}$ and Mo-Ni/ASA fresh reduced catalysts

\subsubsection{Catalyst crystal structure}

X-ray powder diffraction patterns presented in Fig. 2 were recorded to study the crystalline structure of the fresh reduced catalysts.

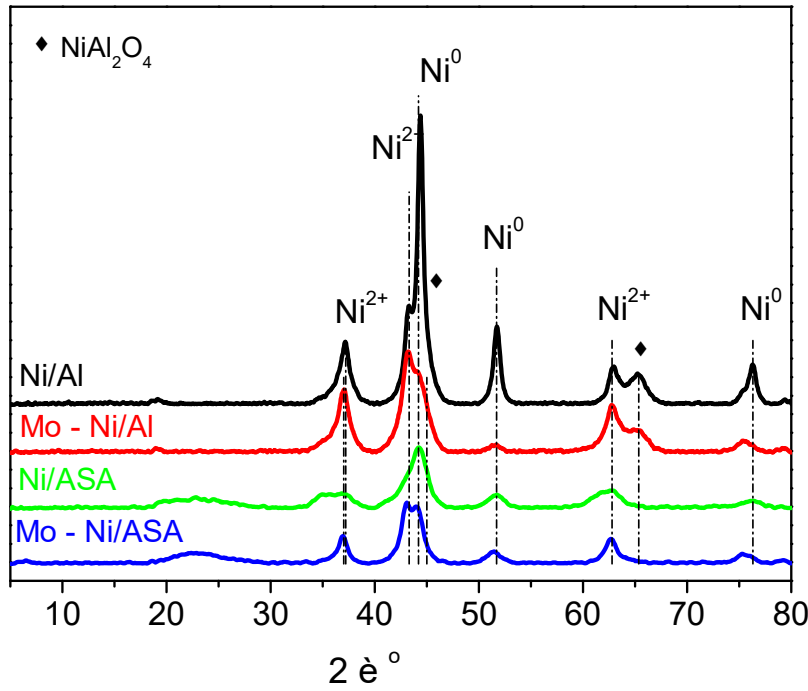

Figure 2. XRD patterns of the fresh reduced catalysts (reduction temperature $400{ }^{\circ} \mathrm{C}$ ) 
Inspection of this figure reveals that three nickel crystal phases, NiO (JCPDS 22-1189), metallic $\mathrm{Ni}$ (JCPDS 04-0850) and $\mathrm{NiAl}_{2} \mathrm{O}_{4}$ (JCPDS 10-0339), can be indentified in all fresh reduced catalysts supported on alumina. No peaks attributed to Mo-phase have appeared in the XRD pattern of the corresponding bimetallic catalyst. This means that high dispersion of this phase has been achieved. However, the addition of Mo to the Ni catalyst supported on alumina affected the relative intensities of XRD peaks of the aforementioned Ni-phases. More precisely, an increase of the intensity of the peak at $2 \theta=43.3^{\circ}$ (the most intense peak of NiO crystal phase, JCPDS 22-1189) and a simultaneous decrease of that of the peak at $2 \theta=44.58^{\circ}$ (the most intense peak of metallic Ni crystal phase, JCPDS 04-0850) are observed. These indicate that the presence of Mo species inhibits the reduction of initially formed nickel oxide phase showing that an interaction between the $\mathrm{Ni}$ and Mo phases takes place. This interaction is in accordance with the fact that the presence of Mo species provoked diminution of the intensity of the peak at $2 \theta=65.37^{\circ}$ indicating an inhibition of $\mathrm{NiAl}_{2} \mathrm{O}_{4}$ formation.

The absence of the latter peak in the XRD patterns of the ASA supported samples indicates no formation of $\mathrm{NiAl}_{2} \mathrm{O}_{4}$ phase on these samples. This can be due to the relative low alumina content ( $28 \mathrm{wt} \%$ ) of the latter support. The Mo addition in the ASA supported sample increased also the $(\mathrm{NiO} /$ metallic $\mathrm{Ni})$ ratio revealing again that the presence of Mo species inhibits the reduction of nickel oxide phase. The above arguments have been corroborated by $\mathrm{H}_{2}$-TPR (see below).

\subsubsection{Catalyst reducibility}

$\mathrm{H}_{2}$-TPR experiments were carried out in order to investigate the effect of support as well as the modification with $\mathrm{Mo}$ on the reducibility of $\mathrm{Ni}$ species and the metal-support interactions. Figure $3 \mathrm{a}$ shows reduction profiles of alumina-supported $\mathrm{Ni}$ and $\mathrm{MoNi}$ catalysts. These profiles involve a wide reduction peak range starting from about $300^{\circ} \mathrm{C}$ and finalizing at about $850^{\circ} \mathrm{C}$. According to the literature $\mathrm{Ni}$-oxo species reduced at temperatures $<500{ }^{\circ} \mathrm{C}$ exhibit weak or not interaction with the support. Such species reduced in the temperature range 500-600 ${ }^{\circ} \mathrm{C}$ are well dispersed and moderately interacting with support surface. Ni-species strongly interacting with the support forming a $\mathrm{NiAl}_{2} \mathrm{O}_{4}$-like phase are reduced at temperatures $>700{ }^{\circ} \mathrm{C}[42-46]$.

As seen (Fig. 3a), when Ni/Al catalyst is modified with small amount of Mo the amount of $\mathrm{H}_{2}$ consumed is diminished especially at high temperatures. This behavior confirms the aforementioned interaction between $\mathrm{Ni}$ and Mo phases. The low $\mathrm{H}_{2}$ consumption observed in the $\mathrm{H}_{2}$-TPR profile of the Mo-Ni/Al sample at high temperatures shows that the presence Mo-phase inhibits the formation of $\mathrm{NiAl}_{2} \mathrm{O}_{4}$-like phase. This result corroborates the XRD finding mentioned above and is in very good agreement with our previous results [36]. Noticeably, peaks due to reduction of Mo oxide species are not observed probably because these are very weak compared to those of abundant Ni-phases. 

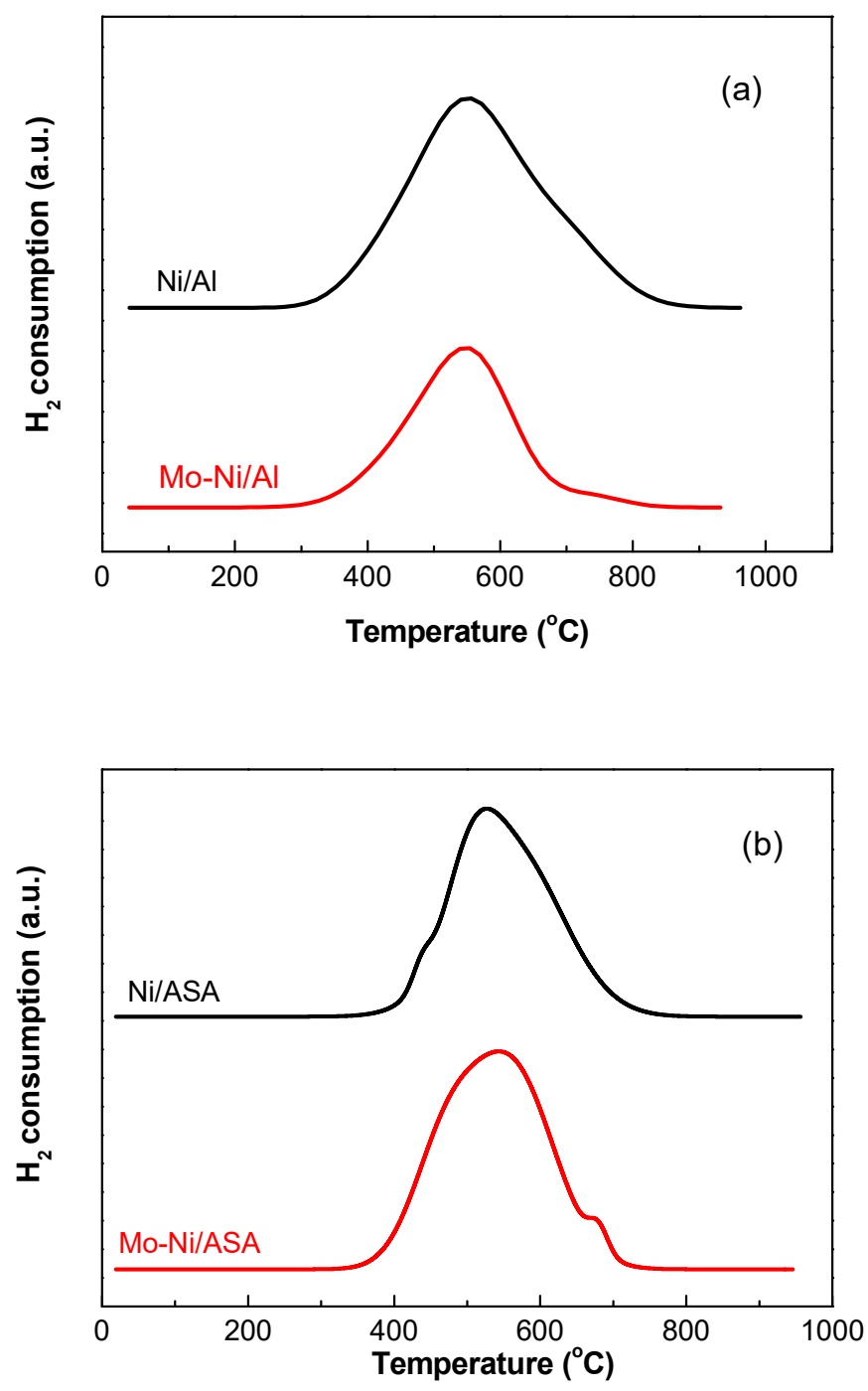

Figure 3. $\mathrm{H}_{2}$-TPR profiles of $\mathrm{Ni} / \mathrm{Al}$ and $\mathrm{Mo-Ni} / \mathrm{Al}$ (a) as well as of Ni/ASA and Mo$\mathrm{Ni} / \mathrm{ASA}$ precursor samples (b).

Focusing our attention on the $\mathrm{H}_{2}$-TPR profile of Ni/ASA sample (Fig. 3b) we have to notice the absence of $\mathrm{H}_{2}$ consumption at temperature higher than $700{ }^{\circ} \mathrm{C}$ previously attributed to the reduction of nickel aluminate-like phase ad/or amorphous $\mathrm{Ni}$ silicate/aluminate species [47]. In this work, the combined XRD and TPR results suggested that those species were not formed on the ASA support. The addition of Mo species in the Ni/ASA catalyst seems to provoke slight changes in the $\mathrm{H}_{2}$-TPR profile retaining the total $\mathrm{H}_{2}$ consumption almost unaffected.

\subsubsection{Supported species determined by Raman spectroscopy}

To get more information about the supported species formed in the prepared samples, especially for the not detected ones by the previously discussed techniques, their Raman spectra have been recorded after drying (overnight at $110^{\circ} \mathrm{C}$ ), decomposition in $\mathrm{He}(450$ ${ }^{\circ} \mathrm{C}$ for $90 \mathrm{~min}$ ) and further reduction in $\mathrm{H}_{2}$ at $450^{\circ} \mathrm{C}$ for $2 \mathrm{~h}$. 
Figure 4 (A) shows representative Raman spectra of prepared samples after drying. In these spectra an intense band appears at $1045 \mathrm{~cm}^{-1}$ assigned to $\mathrm{NO}_{3}{ }^{-}$ions [48] due to the nitrate salt used as $\mathrm{Ni}$ source. This band disappears after the thermal treatment of the samples at $450{ }^{\circ} \mathrm{C}$ for 90 min under He (see Figure 4 (B)). The weak peaks appearing at $467,548,714,973$, and $1287 \mathrm{~cm}^{-1}$ are obviously due to Ni species. These peaks appear also in the Raman spectra of Mo-Ni samples after drying independently of the support used.

The bands appearing at 323, 860 (shoulder) and $904 \mathrm{~cm}^{-1}$ in the spectra of Mo-containing samples indicate the formation of $\mathrm{MoO}_{4}{ }^{2-}$ species with tetrahedral coordination [49] in the early preparation step. From the above it is evident that the use of ammonia as precipitating agent ensured the depolymerization of $\mathrm{Mo}_{7} \mathrm{O}_{24}{ }^{6-}$ species, existing in the salt used as Mo source, to $\mathrm{MoO}_{4}{ }^{2-}$ ones [50] and as a consequence, the Mo dispersion was improved and the formation of crystalline $\mathrm{MoO}_{3}$ was avoided, in good agreement with the study reported by Dzwigaj et al. [51].

The main band of $\mathrm{MoO}_{4}{ }^{2-}$ at $904 \mathrm{~cm}^{-1}$ was slightly shifted to $864 \mathrm{~cm}^{-1}$ after decomposition step (see Figure 4 (B)) and remained there even after reduction with $\mathrm{H}_{2}$ at $450{ }^{\circ} \mathrm{C}$ implying that monomeric Mo-species are also present in the final catalyst. Thus, in accordance with our XRD results, the Raman spectra of Mo-Ni samples, at any state, did not show bands assigned to crystalline $\mathrm{MoO}_{3}$ nanoparticles $\left(663,821\right.$ and $\left.996 \mathrm{~cm}^{-1}\right)$ [52-54]. This induces that the dispersion of Mo species is quite high.
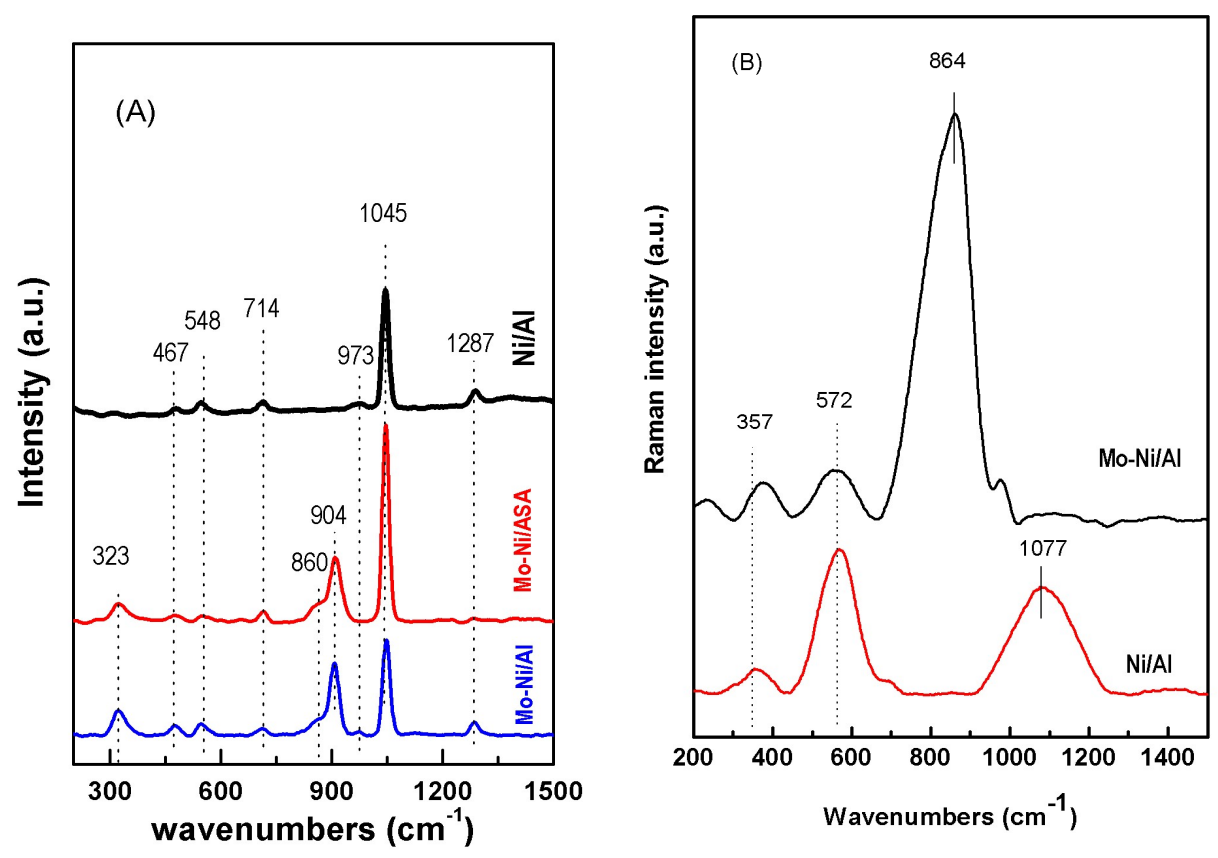

Figure 4. Raman spectra of prepared samples (A) after drying and (B) of Ni/Al and Mo$\mathrm{Ni} / \mathrm{Al}$ after decomposition under He. 


\subsection{Surface Characterization of fresh reduced and spent catalysts}

\subsubsection{Surface acidity of the catalysts}

The acidity of the pre-reduced $\left(\mathrm{H}_{2}\right.$, at $\left.450{ }^{\circ} \mathrm{C}\right)$ catalysts was studied by DRIFT spectroscopy of $\mathrm{NH}_{3}$ adsorption at $120{ }^{\circ} \mathrm{C}$ [55-57]. Figure 5 shows the DRIFTS-NH 3 spectra of the catalysts studied. All catalysts show two band at $1624 \mathrm{~cm}^{-1}$ and in the range of $1220 \mathrm{~cm}^{-1}\left(\boldsymbol{\delta}_{\mathrm{as}}\left(\mathrm{NH}_{3}\right)\right)$ commonly ascribed to Lewis acid sites and a band at $1455 \mathrm{~cm}^{-1}$ assigned to Brønsted-bonded $\mathrm{NH}_{4}{ }^{+}$species $\left(\boldsymbol{\delta}_{\text {as }}\left(\mathrm{NH}_{4}\right)^{+}\right)$[58]. Additionally, the aluminasupported samples exhibited a band at $1500 \mathrm{~cm}^{-1}$ which can be attributed to bending mode of $\mathrm{NH}_{2}$ surface species [59]. Considering the integrated area of the band at $1455 \mathrm{~cm}^{-1}$ (Brønsted-bonded $\mathrm{NH}_{4}{ }^{+}$species), determined after Gaussian deconvolution of the spectra (not shown here), the Brønsted acidity of the catalysts follows the trend: Mo-Ni/ASA $\approx$ $\mathrm{Ni} / \mathrm{ASA}>>\mathrm{Mo}-\mathrm{Ni} / \mathrm{Al}>\mathrm{Ni} / \mathrm{Al}$. The same trend is followed by the Brønsted-to-Lewis $(\mathrm{B} / \mathrm{L})$ acidity ratio involved in Table 3 , as determined from the intensity of the bands at ca. $1455 \mathrm{~cm}^{-1}$ and $1624 \mathrm{~cm}^{-1}$, respectively. Thus, both catalysts supported on ASA exhibited much higher acidities than their alumina-supported ones. Regardless of the support, binary catalysts exhibited larger acidity than their monometallic Ni counterparts.

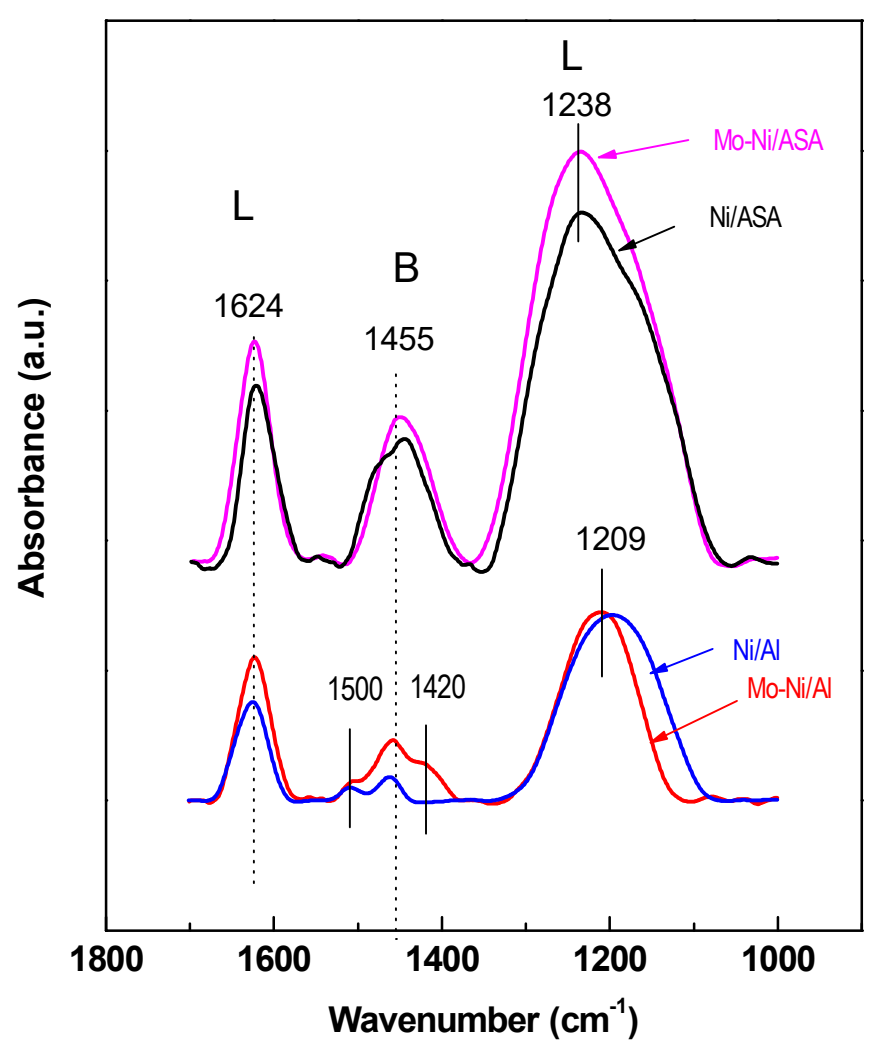

Figure 5. DRIFTS- $\mathrm{NH}_{3}$ spectra of the in situ reduced samples $\left(\mathrm{H}_{2}, 450{ }^{\circ} \mathrm{C}\right)$ 


\subsubsection{X-ray photoelectron spectroscopy (XPS)}

The chemical state and surface composition of fresh reduced alumina and ASA-supported $\mathrm{Ni}$ and Mo-Ni catalysts were revealed by XPS. Table 3 summarizes the peak positions in $\mathrm{eV}$ for the most intense photoelectron peaks. Figures 6 and 7 show the Ni 2p $p_{3 / 2}$ core level spectra recorded over the partially reduced alumina- and ASA-supported Ni and Mo-Ni catalysts, respectively. The A12p XPS spectra of both samples (not shown here) are similar in the spectra pattern, peak position, and symmetry.

Table 3. Binding energies of core levels $(\mathrm{eV})^{\mathrm{a}}$ of the in situ $\mathrm{H}_{2}$-reduced fresh and spent samples

\begin{tabular}{|c|c|c|c|c|}
\hline \multirow[t]{2}{*}{ Catalyst } & \multicolumn{2}{|c|}{$\mathrm{Ni}_{2} \mathrm{p}_{3 / 2}^{\mathrm{a}}(\mathrm{eV})$} & \multicolumn{2}{|c|}{$\operatorname{Mo} d_{5 / 2}{ }^{a}(e V)$} \\
\hline & $\mathrm{Ni}^{0}$ & $\mathrm{Ni}^{2+}$ & $\mathrm{Mo}^{4+}$ & $\mathrm{Mo}^{6+}$ \\
\hline $\mathrm{Ni} / \mathrm{Al}_{\text {fresh }}$ & $852.8(42 \%)$ & $855.8(58 \%)$ & & - \\
\hline $\mathrm{Ni} / \mathrm{ASA}_{\text {fresh }}$ & $853.0(16 \%)$ & $856.2(84 \%)$ & & - \\
\hline Mo-Ni/Alfresh & $852.8(39 \%)$ & $855.8(61 \%)$ & $229.1(40 \%)$ & $232.2(60 \%)$ \\
\hline Mo-Ni/ASA fresh & $855.1(16 \%)$ & $857.0(84 \%)$ & $229.3(55 \%)$ & $232.5(45 \%)$ \\
\hline Mo-Ni/ASA spent & $854.2(41 \%)$ & $856.6(59 \%)$ & $229.5(53 \%)$ & $232.9(47 \%)$ \\
\hline
\end{tabular}

${ }^{a}$ As determined by XPS. The percentage of peak areas is given in parenthesis

The $\mathrm{Ni} 2 \mathrm{p}_{3 / 2}$ core level spectra of all samples are rather broad and complex. Using a program which includes Gaussian/Lorentzian distributions, each $\mathrm{Ni} 2 \mathrm{p}_{3 / 2}$ profile was resolved in two components: ca. 852.8 and $855.8 \mathrm{eV}$. The former $\mathrm{Ni} 2 \mathrm{p}_{3 / 2}$ peak is attributed to $\mathrm{Ni}^{0}$ species whereas the nearly symmetric $\mathrm{Ni} 2 \mathrm{p}_{3 / 2}$ peak appearing at binding energy of $\sim 856 \mathrm{eV}$ accompanied by a shakeup satellite structure at ca $862.0 \mathrm{eV}$, as in the present work, are indicative of the existence of $\mathrm{Ni}^{2+}$ species [60]. As a consequence, in combination with XRD and $\mathrm{H}_{2}$-TPR results, the latter two $\mathrm{Ni}$ characteristic peaks can be assigned to $\mathrm{Ni}^{2+}$ species interacting strongly with alumina surface and to $\mathrm{NiAl}_{2} \mathrm{O}_{4}$ like structure formed on the $\mathrm{Ni} / \mathrm{Al}$ catalyst. The percentage of peak areas is given in parenthesis in Table 3 . As seen, the modification of $\mathrm{Ni} / \mathrm{Al}$ sample with Mo led to a little larger proportion of unreduced $\mathrm{Ni}$ species $(61 \%$ vs. $58 \%)$ indicating a little stronger interaction of $\mathrm{Ni}^{2+}$ ions with the other catalyst components, in good agreement with $\mathrm{XRD}$ and $\mathrm{H}_{2}-\mathrm{TPR}$ information (vide supra). These techniques showed also diminution of $\mathrm{NiAl}_{2} \mathrm{O}_{4}$ phase provoked by addition of Mo. Thus, one can attribute this stronger interaction to the probable formation of amorphous $\mathrm{NiMoO}_{4}$ like structures. The Mo 3d peak shows two doublets, each one with well separated $(\Delta=3.15 \mathrm{eV}) \mathrm{Mo} \mathrm{d}_{5 / 2}$ and Mo3 $\mathrm{d}_{3 / 2}$ spin-orbit components. The observation of two doublets indicates that there are two different Mo species. It is known that Mo3d peaks are asymmetric for molybdenum metal whereas the peaks are symmetric for Mo oxides. Since the peaks are symmetric, the absence of metallic Mo species can be deduced. Indeed, two signals at $232.2 \mathrm{eV}\left(\right.$ Mo $\left.3 \mathrm{~d}_{5 / 2}\right)$ and $235.4 \mathrm{eV}$ (Mo 3 $\mathrm{d}_{3 / 2}$ ) correspond to supported molybdate species in the highest oxidation state [61] whereas the peak at 229.1 
$\mathrm{eV}$ is indicative of Mo(IV) oxo-species. Considering the percentage of the species given in parenthesis in Table 3, the proportion between Mo(IV) and Mo(VI) oxo-species is 4to-6.

Table 4. Surface atomic ratio (from XPS) and bulk atomic ratios (from EDS) of the in situ $\mathrm{H}_{2}$-reduced fresh and spent samples

\begin{tabular}{|c|c|c|c|c|c|c|c|c|}
\hline \multirow{3}{*}{ Catalyst } & \multicolumn{3}{|c|}{$\mathrm{Ni} /(\mathrm{Al}+\mathrm{Si})$} & \multicolumn{3}{|c|}{$\mathrm{Mo} /(\mathrm{Al}+\mathrm{Si})$} & \multirow{3}{*}{$\begin{array}{c}\mathrm{Ni}+\mathrm{Mo}) / \\
(\mathrm{Si}+\mathrm{Al}) \\
\text { XPS }\end{array}$} & \multirow{3}{*}{$\begin{array}{l}\mathrm{Al} / \mathrm{Si} \\
\mathrm{XPS}\end{array}$} \\
\hline & \multicolumn{2}{|c|}{ XPS } & \multirow{2}{*}{$\begin{array}{c}\text { Bulk } \\
\mathrm{Ni}\end{array}$} & \multicolumn{2}{|c|}{ XPS } & \multirow{2}{*}{$\begin{array}{c}\text { Bulk } \\
\text { Mo }\end{array}$} & & \\
\hline & $\mathrm{Ni}^{0}$ & $\mathrm{Ni}^{2+}$ & & $\mathrm{Mo}^{4+}$ & $\mathrm{Mo}^{6+}$ & & & \\
\hline $\mathrm{Ni} / \mathrm{Al} 1_{\text {fresh }}$ & 0.230 & 0.317 & 1.390 & - & - & - & 0.547 & - \\
\hline $\mathrm{Ni} / \mathrm{ASA}_{\text {fresh }}$ & 0.094 & 0.494 & 1.436 & - & - &.- & 0.588 & 2.120 \\
\hline $\mathrm{Mo}-\mathrm{Ni} / \mathrm{Al}_{\text {fresh }}$ & 0.328 & 0.512 & 0.916 & 0.036 & 0.054 & 0.057 & 0.930 & - \\
\hline Mo-Ni/ASA fresh & 0.136 & 0.711 & 0.794 & 0.065 & 0.055 & 0.050 & 0.967 & 2.167 \\
\hline Mo-Ni/ASA spent & 0.247 & 0.355 & - & 0.051 & 0.046 & - & 0.699 & 2.015 \\
\hline
\end{tabular}

The surface XPS atomic ratios compiled in Table 3 indicate that the $\mathrm{Ni}^{0} / \mathrm{Ni}^{2+}$ atomic ratio for the $\mathrm{Ni} / \mathrm{ASA}_{\text {fresh }}$ catalyst calculated from the corresponding percentages is lower than that

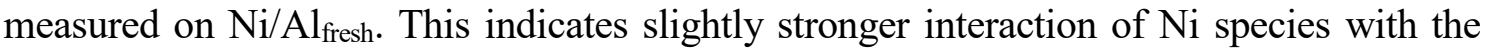
ASA support. This finding is in good agreement with the results obtained by XRD (Fig. 2) and $\mathrm{H}_{2}$-TPR (Fig. 3). The addition of Mo to the Ni/ASA sample seems not to change the aforementioned ratio, which was already high. However, the XPS analysis of the Mo$\mathrm{Ni} / \mathrm{ASA}_{\text {spent }}$ catalyst reveals that the reductive prevailing conditions $\left(T=310^{\circ} \mathrm{C}, P=3.0\right.$ $\mathrm{MPa}, T O S=4 \mathrm{~h}$ ) during the catalysts evaluation tests provoke significant further reduction of $\mathrm{Ni}^{2+}$ species. A very similar Mo species surface exposure found on the surface of both $\mathrm{Mo}-\mathrm{Ni} / \mathrm{Al}$ and $\mathrm{Mo}-\mathrm{Ni} / \mathrm{ASA}$ samples, as deduced from the comparison of the $\mathrm{Mo} / \mathrm{Al}(0.120)$ and $\mathrm{Mo} /(\mathrm{Si}+\mathrm{Al})(0.090)$ atomic ratios of both catalysts. As seen in Figure 9 the surface exposure of $\mathrm{Ni}$ species found on the surface of the catalysts studied depends on their composition. More precisely, the dispersion (XPS Ni/Al or $\mathrm{Ni} /(\mathrm{Al}+\mathrm{Si})$ atomic ratio) of $\mathrm{Ni}$ species is similar at $\mathrm{Ni} / \mathrm{Al}$ catalyst and at $\mathrm{Ni} / \mathrm{ASA}$ one. However, the corresponding surface atomic ratios (XPS) are lower to those calculated taking into account the bulk composition (EDS) of the corresponding catalysts. This indicates that the Ni dispersion is relatively low. However, the very good mixing of the active phase and the support ensures relatively high surface areas (Table 2) in the prepared catalysts, in spite of their high metal loading. On the other hand, the addition of Mo provokes an increase of Ni dispersion in both cases (Mo$\mathrm{Ni} / \mathrm{Al}$ and Mo-Ni/ASA), rendering the corresponding values equal. Finally, it can be mentioned that after $4 \mathrm{~h}$ on-stream the surface exposure of both $\mathrm{Ni}$ and Mo species decreased (see Table 3) indicating some leaching of the active phases under on-stream conditions. This behavior was observed in all catalysts studied. 

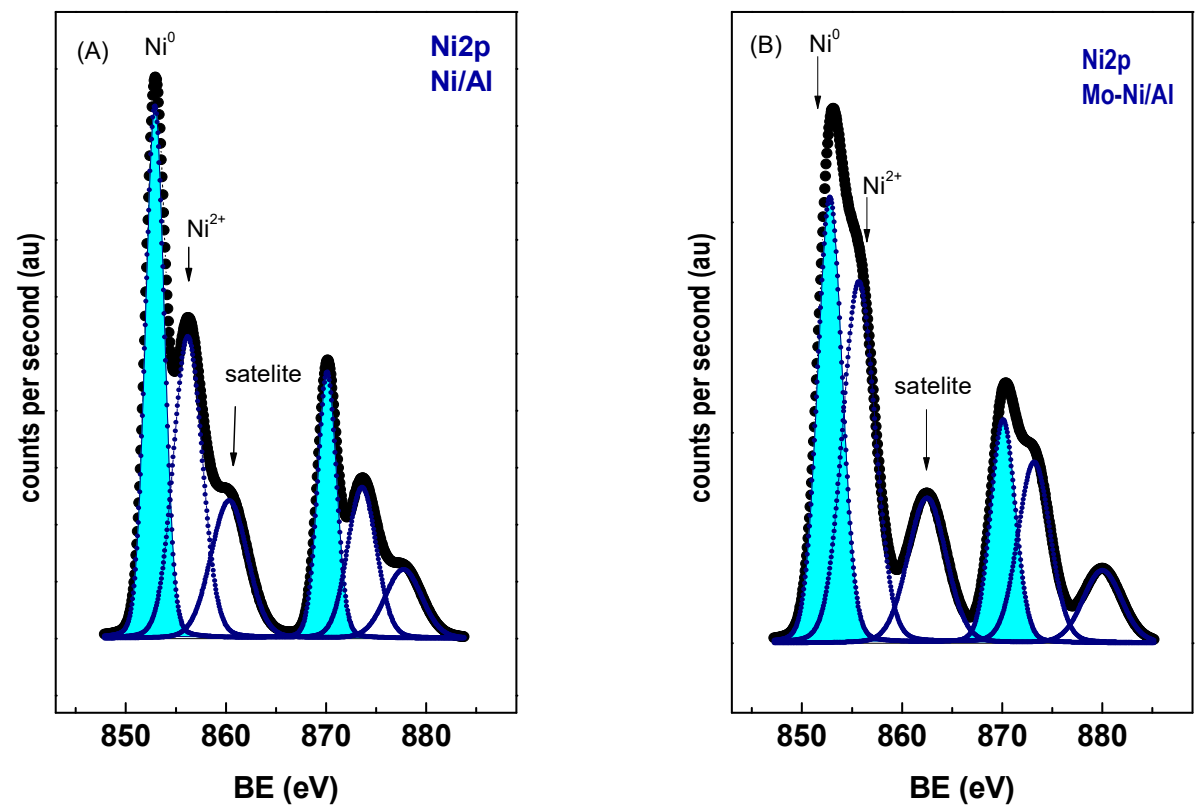

Figure 6. Ni $2 p$ core level spectra of monometallic $\mathrm{Ni} / \mathrm{Al}(\mathrm{A})$ and bimetallic Mo-Ni/Al (B) catalysts reduced with $\mathrm{H}_{2}$.
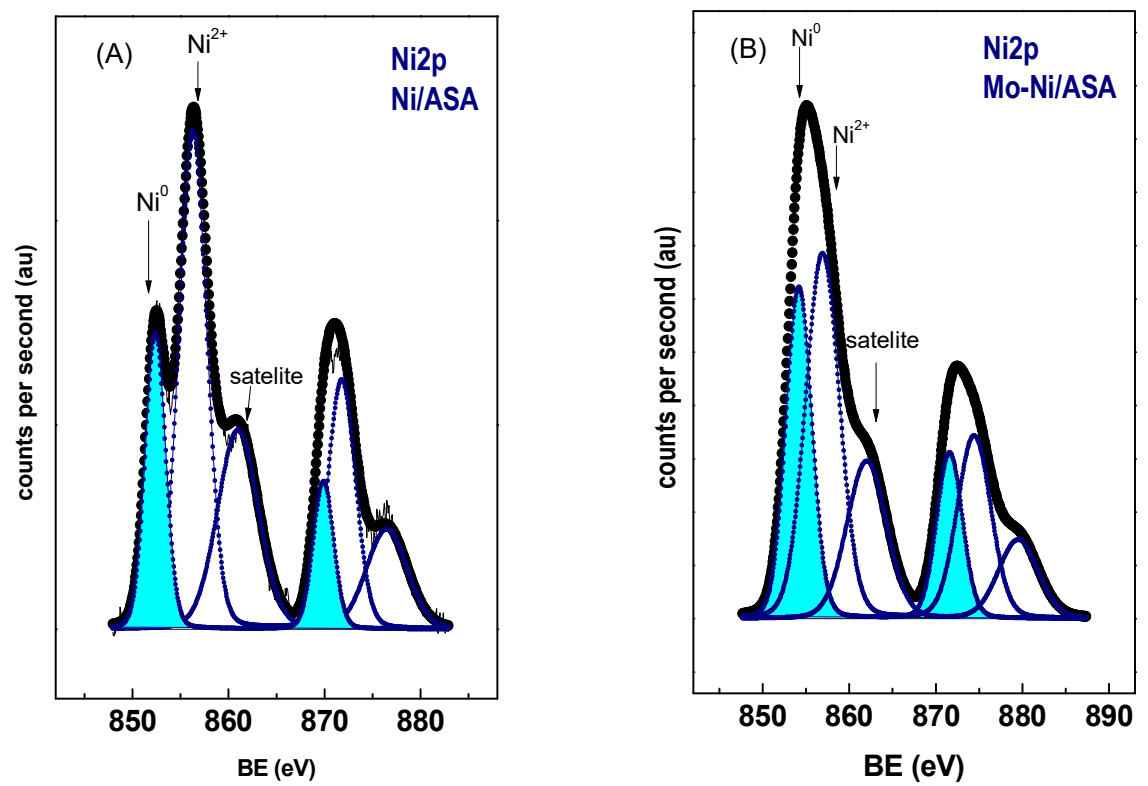

Figure 7. Ni $2 p$ core level spectra of monometallic Ni/ASA (A) and bimetallic Mo$\mathrm{Ni} / \mathrm{ASA}$ (B) catalysts reduced with $\mathrm{H}_{2}$. Components of metallic nickel are in color. 

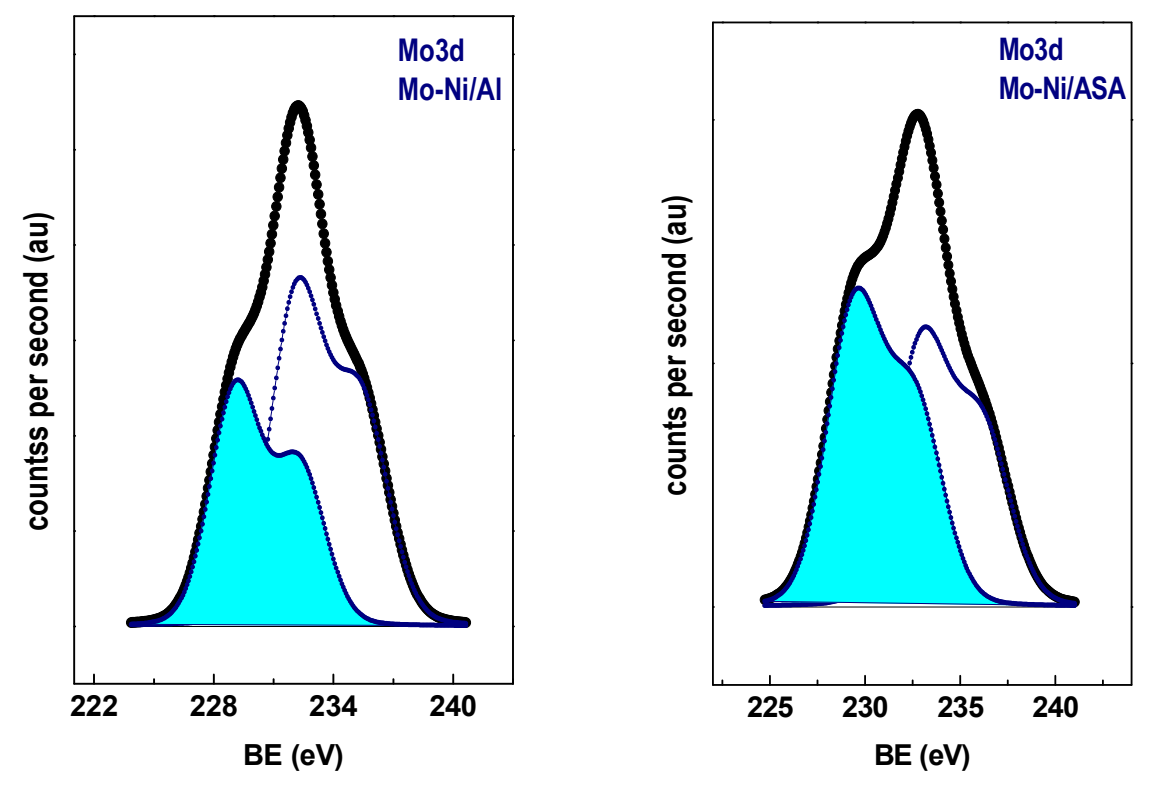

Figure 8. Mo 3d core level spectra of bimetallic Mo-Ni/Al (left) and Mo-Ni/ASA (right) catalysts reduced with $\mathrm{H}_{2}$. Doublet in color belongs to $\mathrm{MoO}_{2}$

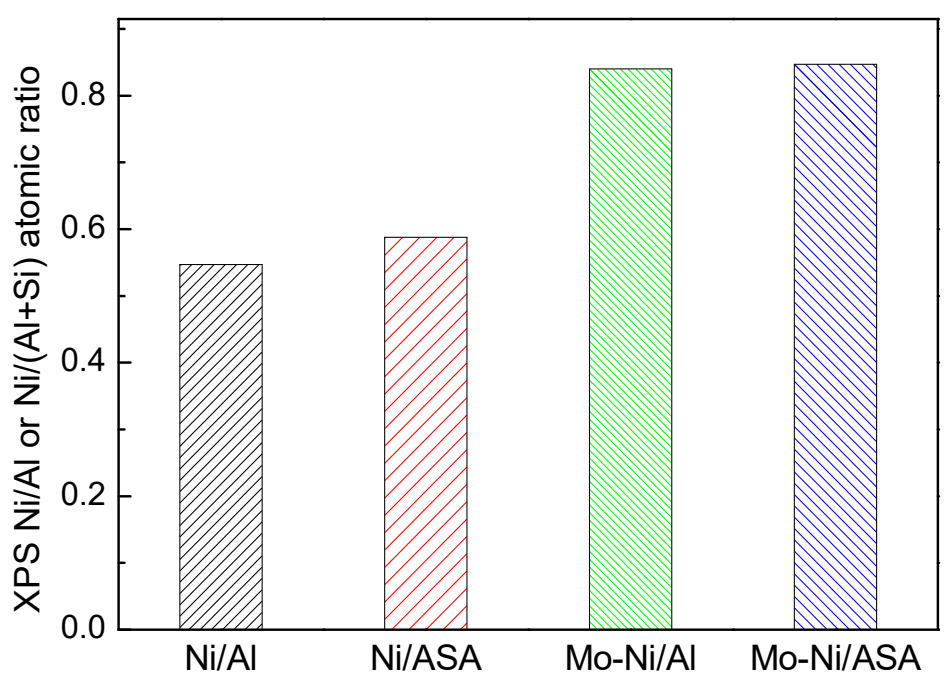

Figure 9 Surface Ni exposure (from XPS) for the catalysts studied.

\subsubsection{DRIFTS of adsorbed CO}

The $\mathrm{Ni}^{2+}$ and $\mathrm{Ni}^{0}$ species were also probed by the DRIFT spectra of $\mathrm{CO}$ adsorbed on the catalysts activated by reduction. The DRIFT spectra, in the region corresponding to the stretching vibration modes, of $\mathrm{CO}$ adsorbed at room temperature on in situ $\mathrm{H}_{2}$-reduced catalysts are shown in Figure 10. According to the literature $[62,63]$ there are two types 
of CO adsorbed on such catalysts appearing DRIFTS bands in the region 2100-1900 $\mathrm{cm}^{-1}$ : linear $\mathrm{CO}$ exhibiting adsorption between 2100 and $2000 \mathrm{~cm}^{-1}$ and bridged $\mathrm{CO}$ exhibiting adsorption below $2000 \mathrm{~cm}^{-1}$ [64]. All pre-treated with $\mathrm{H}_{2}$ catalysts show bands at $2175,2124,2082$ and $2055 \mathrm{~cm}^{-1}$. The latter band exhibits a low frequency shoulder (at $\sim 2025 \mathrm{~cm}^{-1}$ ) suggesting some bridged CO adsorption. Blackmond and Ko [64] have assigned a band appearing at $1960 \mathrm{~cm}^{-1}$ to bridged $\mathrm{CO}$ adsorbed on Ni crystallites. They have found that the intensity of this band decreases as the size of crystallites decreases. Thus, the absence of such a band in the spectra of our samples is a strong indication of a relatively good dispersion of $\mathrm{Ni}$ on the support surface of all catalysts [65]. As the band at ca. $2170 \mathrm{~cm}^{-1}$ has been observed for $\mathrm{NaY}, \mathrm{KY}$ zeolites and pre-reduced $\mathrm{Ni} / \mathrm{HY}$ catalysts [63], the band at $2175 \mathrm{~cm}^{-1}$ can be attributed to carbon monoxide weakly held at centers within the support itself.

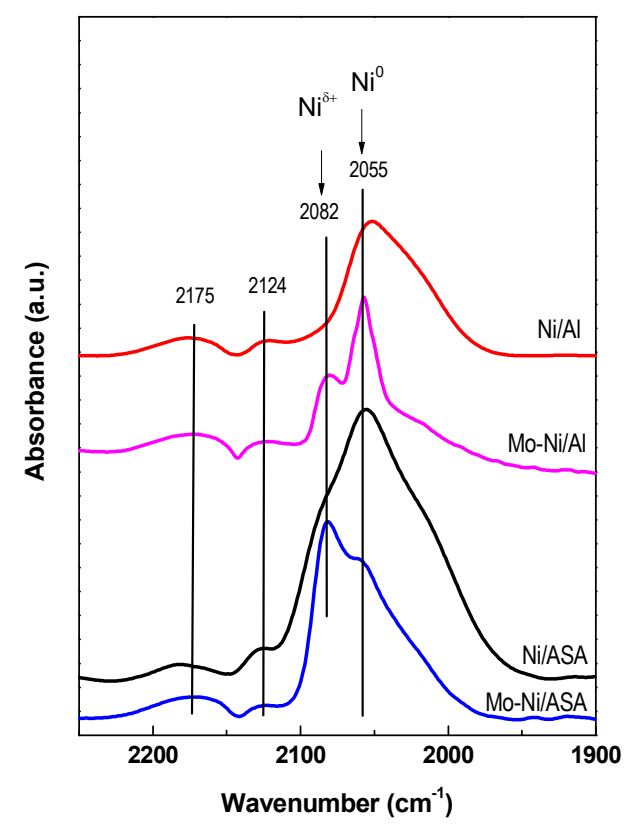

Figure 10. DRIFT spectra of $\mathrm{CO}$ adsorbed at room temperature on $\mathrm{H}_{2}$-reduced $\mathrm{Ni} / \mathrm{Al}$ catalyst.

Focusing our attention on the stretching CO vibration modes between 2100 and 2000 $\mathrm{cm}^{-1}$ in Figure 10, the most dominant features in DRIFT-CO spectra are the intense bands at 2055 and $2082 \mathrm{~cm}^{-1}$ indicative of linearly bonded CO. Differences are observed between alumina and silica-alumina $\mathrm{Ni}$ and Mo-Ni catalysts, which could be assigned to differences in the $\mathrm{Ni}$ and Mo species dispersion. The poor resolution of the spectra of $\mathrm{CO}$ adsorbed on $\mathrm{Ni} / \mathrm{ASA}$ catalyst can be explained as due to the local perturbations of $\mathrm{CO}$ molecule by the strong electrostatic field of the Si-O-Al bridges located in the inner support porous structure. Similar poor resolution of the FTIR-CO spectra was observed 
previously for Pt/HY zeolite [66]. According to Peri et al. [67], the weakly adsorbed CO gives bands at 2070 and $2090 \mathrm{~cm}^{-1}$ which are assigned to $\mathrm{CO}$ held by isolated $\mathrm{Ni}^{0}$ atoms or at $\mathrm{Ni}$ sites adjacent to oxygen atoms or oxide support of $\mathrm{Ni} / \mathrm{Al}_{2} \mathrm{O}_{3}$ catalyst. Considering the FTIR study of $\mathrm{CO}$ adsorption on pre-reduced Ni/HY catalysts [66,68], the bands at ca. $2055 \mathrm{~cm}^{-1}$ and $2082 \mathrm{~cm}^{-1}$ may be attributed to carbon monoxide adsorbed on nickel in partially oxidized state $\left(\mathrm{Ni}^{\delta+}\right)$ and on isolated $\mathrm{Ni}^{0}$ atoms, respectively. Thus, the DRIFT$\mathrm{CO}$ results obtained with all catalysts may be interpreted in terms of the presence of $\mathrm{Ni}^{\delta^{+}}$ and $\mathrm{Ni}^{0}$ species. The most apparent differences between the catalysts are the relative amount of these species. As deduced from the intensities of the bands at $2055 \mathrm{~cm}^{-1}$ and $2082 \mathrm{~cm}^{-1}$ and the shoulder appearing below $2000 \mathrm{~cm}^{-1}$ in the monometallic samples, one can argue that: (i) the latter samples have relatively low dispersion of Ni phase, (ii) the ASA support seems to favor $\mathrm{Ni}^{\delta+}$ formation at the expense of $\mathrm{Ni}^{0}$, (iii) Mo addition favors also this formation independently of the support. These arguments are in full agreement with the above reported results obtained by XRD, $\mathrm{H}_{2}$-TPR and XPS.

\subsubsection{Morphology of fresh reduced catalysts determined by SEM}

Figure 11 illustrates the SEM images for the reduced samples studied. Both alumina supported samples exhibit at nanoscale a "flower" like morphology. More precisely, agglomerates with nano-flake structure constitute flower like assemblies. We are noting that this structure does not depend on the presence of molybdenum species. The formation of hierarchical NiO flake-flower architectures following a hydrothermal precipitation procedure in the presence or absence of a surfactant and using ammonia or urea as precipitating agents has been reported several times in the last years [69-72]. The mechanistic route followed upon the formation of such architectures has been described elsewhere [37].

Taking into account the above we may easily attribute the $\mathrm{NiO}$ like flake-flower architectures obtained in the samples NiAl and MoNiAl to their high nickel content. It seems that the activation by reduction as well as the presence of amorphous alumina and the well dispersed Mo(IV) and Mo(VI) oxo-phases do not disturb the nano-flower architectures dictated by the initially formed $\mathrm{Ni}(\mathrm{OH})_{2}$. Ni/ASA sample exhibited the same "flower" like morphology despite the stronger Ni phase-support interaction deduced above (see XRD, $\mathrm{H}_{2}$-TPR, XPS and DRIFTS-CO results). However, the addition of Mo to the latter catalyst changed the "flower" like morphology to a granular one confirming an additional strong interaction between the two supported phases. 


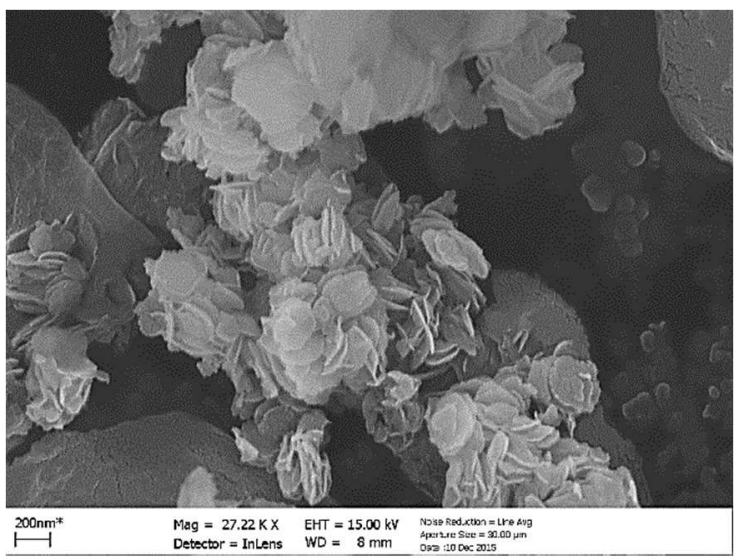

$\mathrm{Ni} / \mathrm{Al}$

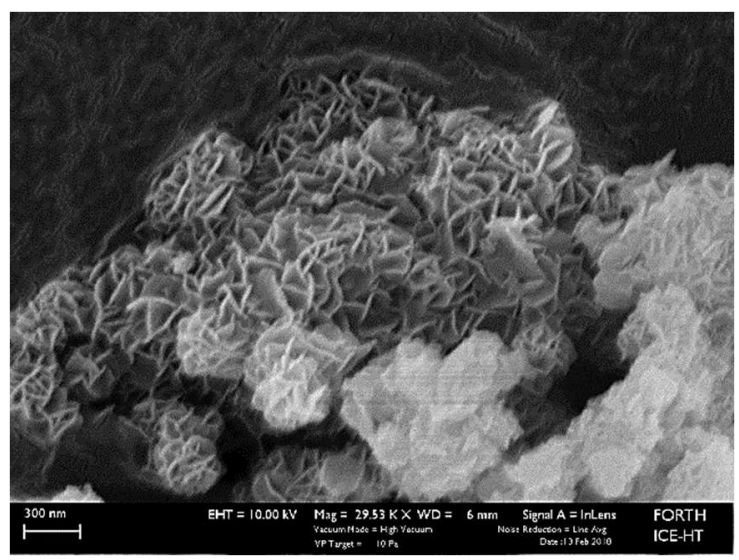

$\mathrm{Ni} / \mathrm{ASA}$

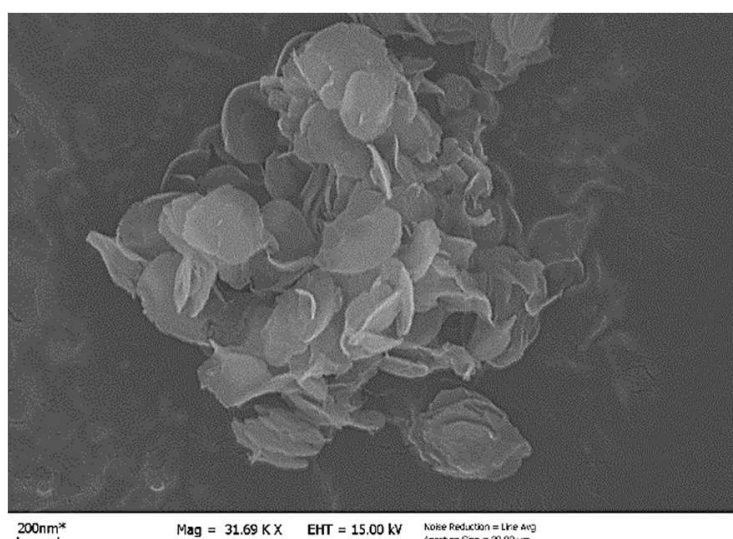

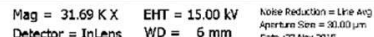

$\mathrm{MoNi} / \mathrm{Al}$

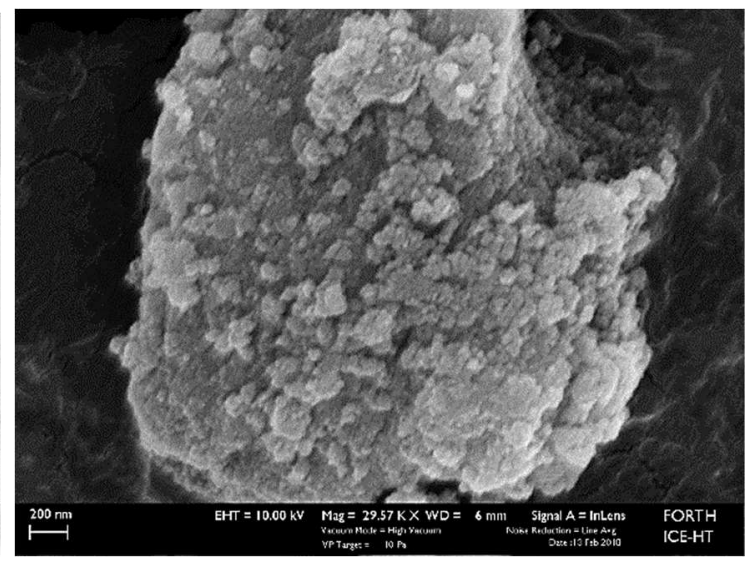

$\mathrm{MoNi} / \mathrm{ASA}$

Figure 11. SEM micrographs of the activated samples.

\subsubsection{Structure of spent catalysts revealed by TEM and HRTEM}

The Ni particle size distribution was measured on the TEM micrographs presented in Figure 12 (left) taking into account the statistical analysis performed on about 250 particles (Fig. 12-right).

Inspection of this figure shows that a very narrow Ni particle distribution of Lorentz type centered at $7.53 \mathrm{~nm}$ is achieved in the $\mathrm{Ni} / \mathrm{Al}$ catalyst. Concerning Ni/ASA catalyst the $\mathrm{Ni}$ particle size distribution is also narrow but its maximum is shifted towards lower size $(3.98 \mathrm{~nm})$. The addition of Mo provokes a shift of the aforementioned distribution peaks to $3.05 \mathrm{~nm}$ for Mo-Ni/Al catalyst and $3.72 \mathrm{~nm} \mathrm{Mo-Ni/ASA}$ one proving the dispersing action of Mo independently of the support used, in good agreement with XRD and XPS results.

Regardless of the Mo addition, all TEM micrographs show nearly spherically shaped Ni particles. The crystal planes of the metallic nickel (2 00 and 220 ) and nickel oxide (2 2 0 ) were detected in these HRTEM images revealing that a fraction of nickel oxide remains unreduced even after catalytic test conditions. This result is in very good agreement with that obtained by XRD and XPS (see Table 3). Structural details for the spent Ni-based catalysts were obtained by HRTEM technique (Fig. 13). 

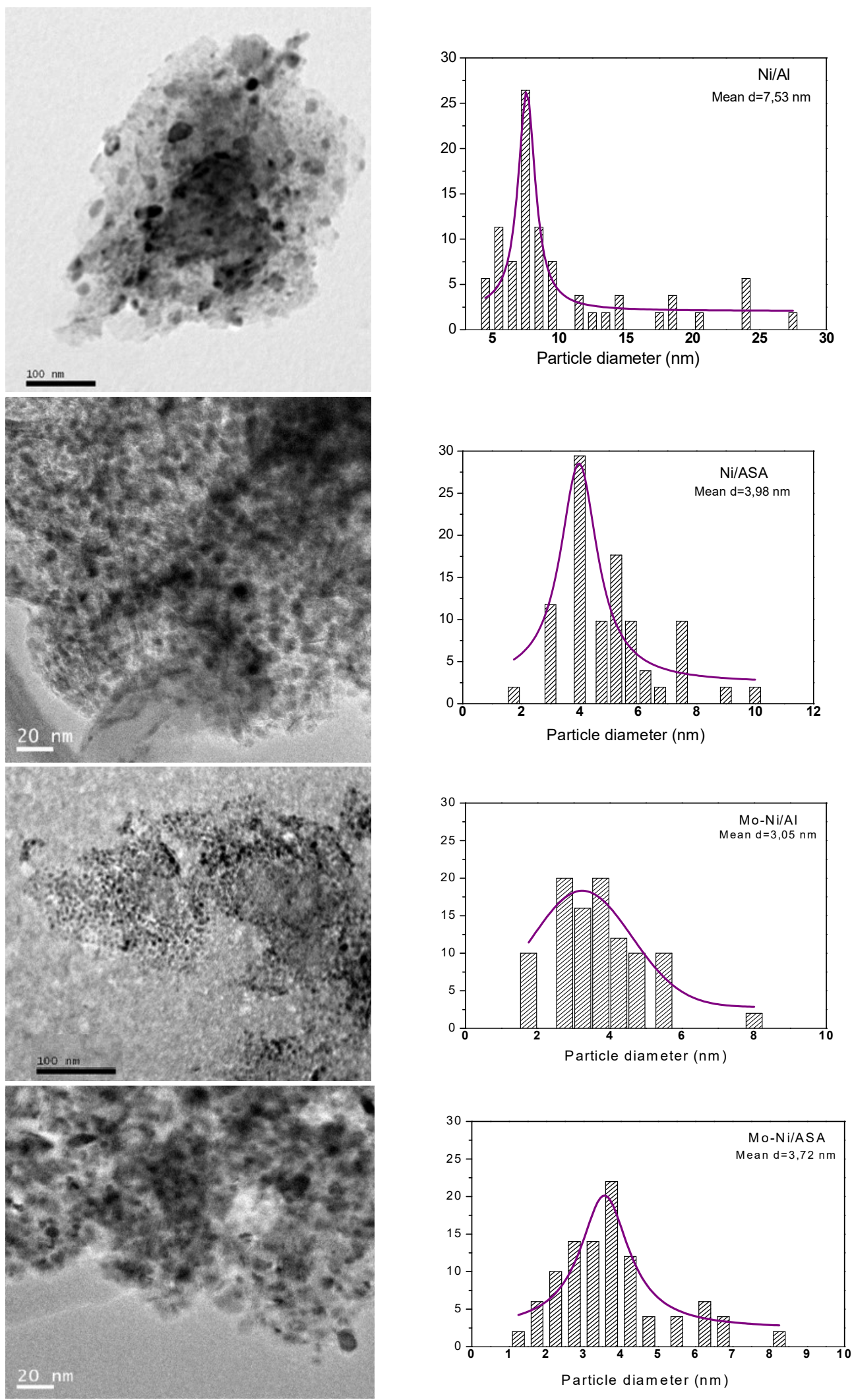

Figure 12. TEM micrographs of the spent $\mathrm{Al}$ and ASA-supported Ni and Mo-Ni catalysts (left) and statistical analysis of particle size distribution (right). 

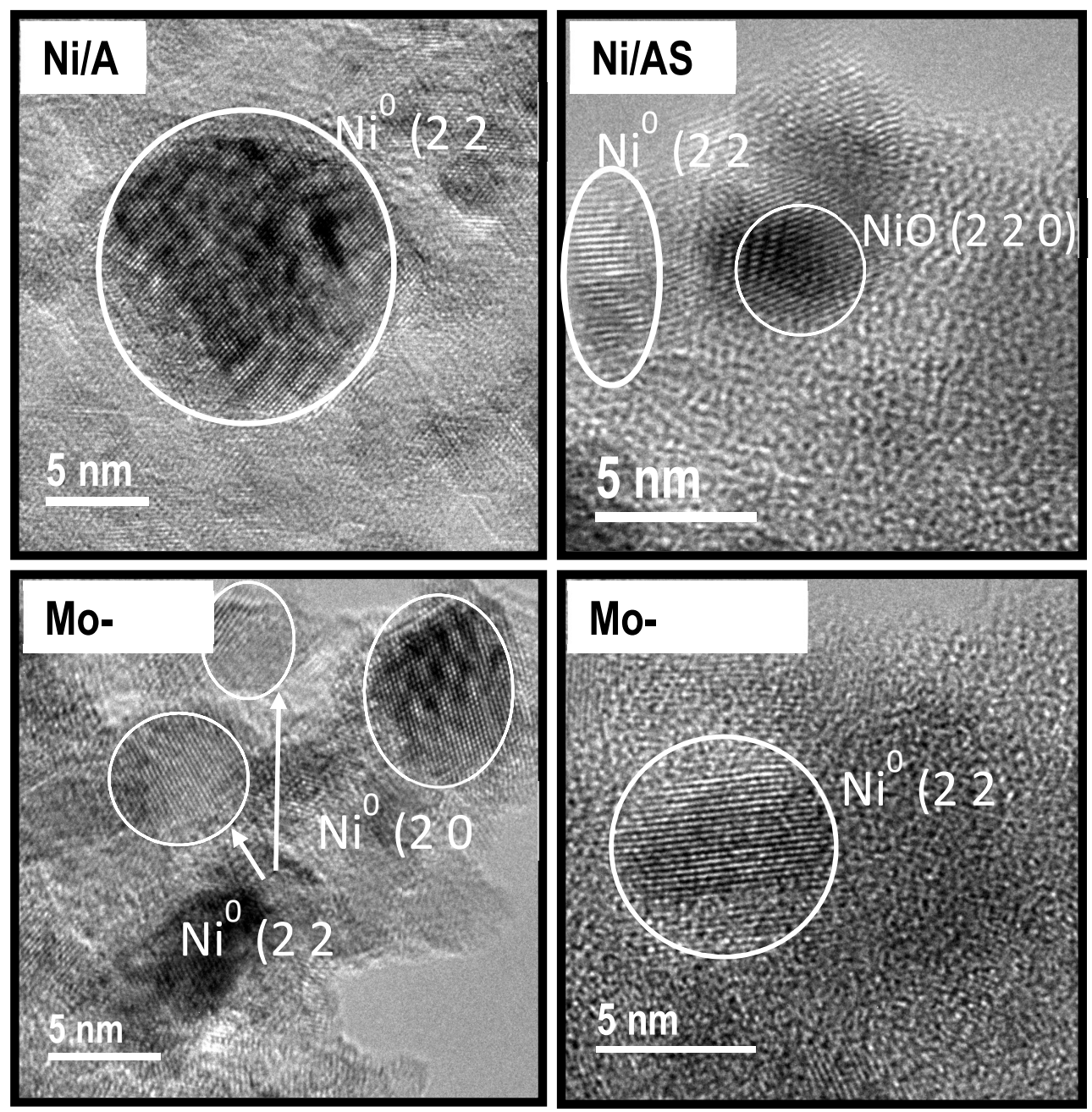

Figure 13. HRTEM images of the spent $\mathrm{Al}$ and ASA-supported Ni and Mo-Ni catalysts.

\subsection{Catalyst activity}

Figure 14 shows the phenol conversion as a function of reaction time at temperature $310^{\circ} \mathrm{C}$ and total $\mathrm{H}_{2}$ pressure of $3.0 \mathrm{MPa}$. As seen, monometallic Ni catalysts were initially very active in the HDO of phenol reaction (more than $40 \%$ of phenol conversion was achieved after $1 \mathrm{~h}$ on-stream). The initial activity of $\mathrm{Ni} / \mathrm{Al}$ catalyst was much higher than that of Ni/ASA one. The dispersion of Ni phase in both samples, deduced from XPS results, does not differ very much. However, the Ni particle size distributions obtained by TEM show that smaller particles are formed on the ASA support. One can suppose that the bigger Ni particles formed on alumina surface result to weaker active phase support interaction facilitating the reduction of $\mathrm{Ni}$ in agreement with the $\mathrm{H}_{2}$-TPR results presented above. This can explain the higher initial activity of $\mathrm{Ni} / \mathrm{Al}$ catalyst.

The catalytic behavior of monometallic samples during the course of reaction is different as the activity of the $\mathrm{Ni} / \mathrm{Al}$ catalyst is decreased with $\operatorname{TOS}(32 \%$ within $3 \mathrm{~h})$, while that of the $\mathrm{Ni} / \mathrm{ASA}$ one is increased $(34.4 \%$ within $3 \mathrm{~h}$ ) being the latter more active after $4 \mathrm{~h}$ onstream. It is well known that catalyst deactivation upon HDO processes is due mainly to three factors: (i) coke deposition, (ii) active phase sintering, and (iii) active phase leaching. In the case of $\mathrm{Ni} / \mathrm{Al}$ catalyst the most important factor seems to be the first one. 
Active phase sintering is not probable, because thermal pre-treatment of the samples at $450^{\circ} \mathrm{C}$ is expected to stabilize active phase against sintering at reaction conditions $\left(\mathrm{T}=310^{\circ} \mathrm{C}\right)$. As similar active phase leaching has been observed in all cases by XPS analysis of the fresh and spent catalysts (Table 4), this factor cannot explain the deactivation observed only over $\mathrm{Ni} / \mathrm{Al}$ catalyst.

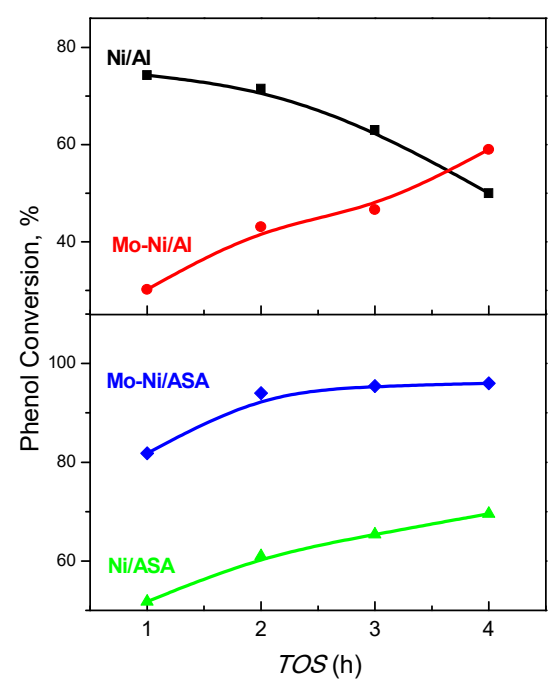

Figure 14. Conversions of phenol over Ni-based catalysts with the time on stream $(T=$ $310^{\circ} \mathrm{C}, P_{\mathrm{H} 2}=3.0 \mathrm{MPa}$ and $W H S V=107.5 \mathrm{~h}^{-1}$ )

Concerning deactivation during hydrotreating of O-containing compounds by coke deposition is well established that the catalyst support plays a key role [73]. The surface acidity of support is crucial in this case [74]. As to the Ni/Al catalyst the coke deposition is expected to be determined by two catalytic functions: the acidity from the alumina support and the hydrogenation ability of coke precursors from Ni. Indeed, it was reported that the presence of weak Lewis acid sites on alumina surface favours enhanced coke formation during HDO reaction [75].

In this work, the partially reduced $\mathrm{Ni} / \mathrm{Al}$ is unique catalyst showing deactivation during reaction time. One could attribute this behavior to its largest Lewis acidity, as deduced from its lowest Brønsted-to-Lewis acidities ratio among the catalysts studied (Table 2). It is well known that the Lewis centres are involved in the polymerization of coke precursors [76]. In addition, the reactivity of coke is closely related to the texture of the catalyst [77]. In this sense, the lowest specific BET surface area of Ni/Al favoured the catalyst deactivation by coke deposition. On the other hand, it is known that the coke formed on metal sites is more hydrogenated whereas the coke formed on the acid sites of support is more polymerized and requires more severe conditions during the regeneration process [77].

The Mo addition to Ni/Al catalyst reversed its deactivation and the Mo-Ni/Al catalyst was activated during time on stream. There are many examples in literature of multi- 
metallic catalysts in which the association of two or more metals has a beneficial influence on diminishing the catalyst deactivation by coke [78]. The activity enhancement observed over the Ni/ASA catalyst with TOS could be attributed to a further reduction of Ni-phase upon reaction. In conclusion, ASA support has a positive effect on the catalytic performance of Ni catalysts. This effect could also be attributed to the higher acidity of the ASA supported catalysts (Figure 5).

The addition of Mo to the Ni/Al catalyst (Mo-Ni/Al) changed dramatically the catalytic performance of this sample. More precisely, a significantly lower initial phenol conversion ( $1 \mathrm{~h}$ on-stream) was observed over Mo-Ni/Al catalyst. This could be attributed to higher $\mathrm{NiO}$ content of this sample after activation, as we have concluded from XRD, XPS and $\mathrm{H}_{2}-\mathrm{TPR}$ results. In contrast to the $\mathrm{Ni} / \mathrm{Al}$ catalyst, the activity of $\mathrm{Mo}-\mathrm{Ni} / \mathrm{Al}$ increases with the time on stream. This behavior could be explained taking into account that the NiO phase being initially on the partially reduced Mo-Ni/Al sample is further reduced during the reaction under high $\mathrm{H}_{2}$ pressure. The fact that the latter sample becomes more active (after $4 \mathrm{~h}$ on-stream) than its monometallic counterpart is in accordance with the increased $\mathrm{Ni}$ phase dispersion provoked by Mo addition (TEM and XPS results), as well as with the relatively higher acidity of the Mo-Ni/Al catalyst (Figure $5)$.

The Mo addition in the Ni/ASA sample increased also its HDO activity very much. The activity of the Mo-Ni/ASA sample increases (as in the case of Ni/ASA sample) with the TOS approaching almost total conversion after $3 \mathrm{~h}$ on-stream. The activity of this catalyst is higher than that of the $\mathrm{Mo}-\mathrm{Ni} / \mathrm{Al}$ one, revealing one more time the positive effect of the ASA support on the catalytic performance. The very high activity of the Mo-Ni/ASA catalyst could be attributed to the largest density of Lewis and Brønsted acid sites detected on its surface by DRIFT-NH $\mathrm{NH}_{3}$ spectroscopy (Figure 5).

Figure 15 compares the phenol conversions obtained over the partially reduced $\mathrm{Ni}$-based catalysts studied with that of a commercial $\mathrm{NiMoP}(\mathrm{S}) / \gamma-\mathrm{Al}_{2} \mathrm{O}_{3}$ catalyst at $T O S$ equal to 4 $\mathrm{h}$, temperature $310^{\circ} \mathrm{C}$ and total $\mathrm{H}_{2}$ pressure of $3.0 \mathrm{MPa}$. As seen, all the partially reduced Ni-based catalysts proved to be more active in the HDO of phenol (phenol conversion higher than $40 \%$ ) in comparison with the commercial $\mathrm{NiMoP}(\mathrm{S}) / \gamma-\mathrm{Al}_{2} \mathrm{O}_{3}$ catalyst activated by sulfidation. The addition of Mo provoked increase of phenol conversion equal to $18 \%$ in the case of the alumina supported catalyst. The corresponding increase in the case of ASA supported one was 38\%, approaching almost total conversion (96\%). Thus, regardless of the support, the addition of Mo to Ni catalysts led to enhancement of the catalyst activity. Noticeably, the most active Mo-Ni/ASA catalysts is about 2.5 times more active than the commercial $\mathrm{NiMoP}(\mathrm{S}) / \gamma-\mathrm{Al}_{2} \mathrm{O}_{3}$ catalyst used as reference. However, one have to take into account that the amount of supported metals used in the lab-made catalysts studied herein is about four times larger than that of the commercial one. On the other hand, is well known that sulfide catalysts undergo desulfurization upon long term bio-oil HDO processes. Sulfur removal from catalyst active sites affects adversely the deoxygenation activity of these catalysts [79]. 


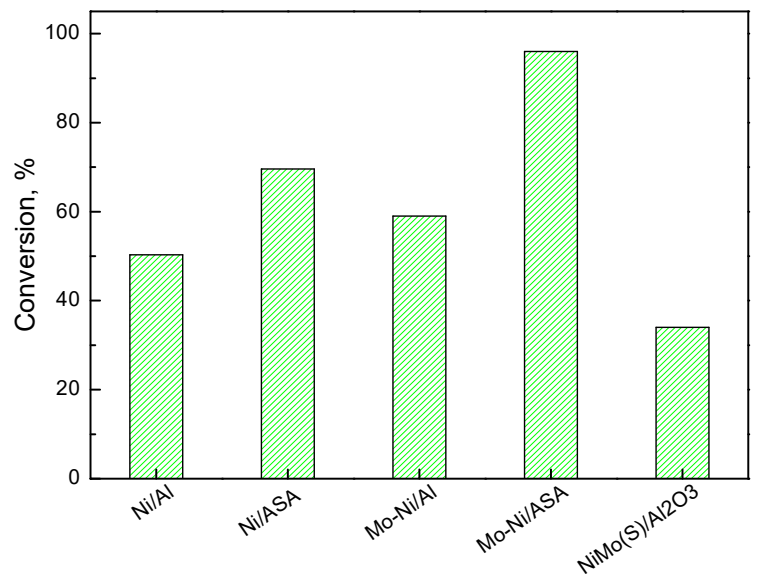

Figure 15. Conversions of phenol over Ni-based catalysts and a commercial one $(T O S=$ $4 \mathrm{~h}, T=310^{\circ} \mathrm{C}, P_{\mathrm{H} 2}=3.0 \mathrm{MPa}$ and $W H S V=107.5 \mathrm{~h}^{-1}$ )

Over Ni-based catalysts prepared for this study cyclohexane $(\mathrm{CH})$, and cyclohexanol $(\mathrm{CHO})$ are mainly produced along with the other minor products such cyclohexene (CHE) and benzene (B) from phenol conversion. Table S1 involves conversion and selectivity values obtained over the catalysts studied. As seen in Figure 16 the addition of Mo in the $\mathrm{Ni}$ catalysts enhances the yield of $\mathrm{O}$-free products. This enhancement is extremely high over the Mo-Ni/ASA catalyst, revealing the positive effect of ASA support on the HDO performance of the catalyst.

Decalin conversion values obtained were generally too low. Thus, the produced hydrocarbons (e.g. cyclohexane) are not expected to influence the yield values of O-free products presented in Figure 16. On the other hand, taking into account that the decalin dehydrogenation products consist only a small portion of decalin conversion products, we can conclude that the $\mathrm{H}_{2}$ produced is insufficient for HDO of phenol.

HDO of model molecules found in bio-oils is a hot issue in the recent literature. $\mathrm{Ni}$ catalysts supported on various supports (e.g. $\mathrm{Al}_{2} \mathrm{O}_{3}$ [80,81], $\mathrm{SiO}_{2}[82,83], \mathrm{TiO}_{2}[80,81]$, $\mathrm{ZrO}_{2}[80,82], \mathrm{SBA}-15$ [83,84], $\mathrm{SiO}_{2}-\mathrm{Al}_{2} \mathrm{O}_{3}$ [85,86], zeolites [87-90], activated carbon [90]) or unsupported ones [91] have attracted great interest of researchers because of the availability and the ability for accelerating hydrogen transferring reactions of this metal.

Partially reduced Mo oxides have been also proved active for HDO reactions [92]. Their activity seemed to be closely related to the availability of $\mathrm{Mo}^{5+}$ species considered as active Mo oxide defects [93]. Such species are stabilized by partial carburization of $\mathrm{MoO}_{\mathrm{x}}$ surface upon reaction [94]. A link between intermediate $\mathrm{Mo}\left(\mathrm{Mo}^{5+}\right.$ and $\left.\mathrm{Mo}^{3+}\right)$ states and $\mathrm{HDO}$ activity has been also found for $\mathrm{MoO}_{3}$ supported on various metal oxide supports $\left(\mathrm{SiO}_{2}, \mathrm{Al}_{2} \mathrm{O}_{3}, \mathrm{TiO}_{2}, \mathrm{CeO}_{2}\right.$, and $\left.\mathrm{ZrO}_{2}\right)$ [95]. However, the aforementioned intermediate oxidation states Mo-species is not abundant on $\mathrm{Al}_{2} \mathrm{O}_{3}$ and $\mathrm{SiO}_{2}$ resulting to catalysts with low HDO activities [36,95]. Hewer et al [96] compared the HDO activities of NiMo reduced catalysts supported on SBA-15, SAPO-11 and alumina using anisole as model compound. They found that active phase dispersion and catalysts acidity are crucial 
factors for HDO process. In this work the conventional $\frac{N i}{N i+M}=0.3$ atomic ratio of HDS catalysts has been adopted. Thus, the yield to deoxygenated products does not exceed $20 \%$ at $300^{\circ} \mathrm{C}$. It has been found that increase of the $\frac{N i}{N i+M o}$ atomic ratio dramatically enhances the HDO activity [36,97]. Combining the above discussed literature findings with our results one can conclude that, as $\mathrm{Mo}^{5+}$ and $\mathrm{Mo}^{3+}$ have not been detected (XPS) in the catalysts studied in the present work, the promoting action of Mo should be attributed to the induced increase of Ni dispersion (XRD, XPS, TEM) and catalyst acidity $\left(\mathrm{NH}_{3}\right.$-DRIFT) as well as to the diminution of the formation of inactive $\mathrm{NiAl}_{2} \mathrm{O}_{4}$ phase (XRD, $\mathrm{H}_{2}$-TPR) when alumina is used as support.

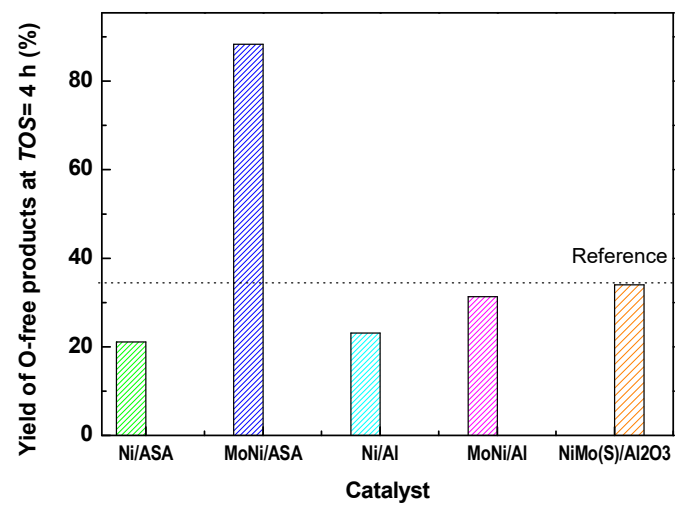

Figure 16. Yields of $\mathrm{O}$-free products in the HDO of phenol $\left(T=310^{\circ} \mathrm{C}, P_{\mathrm{H} 2}=3.0 \mathrm{MPa}\right.$ and $\left.W H S V=107.5 \mathrm{~h}^{-1}, T O S=4 \mathrm{~h}\right)$ over Ni-based catalysts.

\section{Conclusions}

Alumina and amorphous silica-alumina-supported $\mathrm{Ni}$ and Mo-Ni catalysts have been prepared and studied in the HDO of phenol. $\mathrm{MoO}_{\mathrm{x}}$ acts as promoter of the Ni-based catalysts by increasing $\mathrm{Ni}$ dispersion and catalyst acidity and decreasing the formation of inactive $\mathrm{NiAl}_{2} \mathrm{O}_{4}$ phase. The Mo-Ni/ASA catalyst was the most active and selective for O-free products. The high HDO activity of this sample was probably linked with both the Mo promoting action and the high acidity of the ASA support. The yield of O-free products obtained over the latter catalyst was much higher than that obtained over a commercial $\mathrm{NiMoP}(\mathrm{S}) / \mathrm{Al}_{2} \mathrm{O}_{3}$ sulfide catalyst having much lower metal content.

\section{Acknowledgments}

In memory of Prof. José Luis García Fierro. The authors express their gratitude to Drs. P. Castaño and R. Palos Urrutia (University of the Basque Country UPV/EHU, Spain) for their contribution to the GC/MS analysis and to Drs. L. Pascual and M. Capel (ICP-CSIC, Spain, for their HRTEM measurements. Economic support from Comunidad de Madrid (Project CAM S2013/MAE-2882) is gratefully acknowledged. 


\section{References}

1. E. Furimsky, Appl. Catal. A 199 (2000) 147-190.

2. D.C. Elliot, Fuels 21 (2007) 1792-1815.

3. Q. Bu, H. Lei, A.H. Zacher, L. Wang, S. Ren, J. Liang, Y. Wei, Y. Liu, J. Tang, Q. Zhang, R. Ruan, Bioresour. Technol. 124 (2012) 470-477.

4. T.R. Viljava, R.S. Komulainen, T. Selvam, A.O.I. Krause, Stud. Surf. Sci. Catal. 127 (1999) 145-152.

5. E.F. Iliopoulou, S.D. Stefanidis, K.G. Kalogiannis, A. Delimitis, A.A. Lappas, K.S. Triantafyllidis, Appl. Catal. B. 127 (2012) 281-290.

6. Y. Yang, C. Ochoa-Hernández, V.A. de la Pena O’Shea, P. Pizarro, J.M. Coronado, D.P. Serrano, Appl. Catal. B 145 (2014) 91-100.

7. A.R. Ardiyanti, S.A. Khromova, R.H. Venderbosch, V.A. Yakovlev, H.J. Heeres, Appl. Catal. B 117-118 (2012) 105-117.

8. M. A. Machado, S. He, T. E. Davies, K. Seshan, V. T. Silva, Catal. Today 302 (2018) 161-168.

9. X. Li, X. Luo, Y. Jin, J. Li, H. Zhang, A. Zhang, J. Xie, Renew. Sust. Energ. Rev. 82 (2018) 3762-3797.

10. X. Zhao, L. Wei, S. Cheng, J. Julson, Catalysts 7(3) (2017) 83, doi:10.3390/catal7030083.

11. A. Krutof, K. Hawboldt, Renew. Sust. Energ. Rev. 59 (2016) 406-419.

12. M. Patel, A. Kumar, Renew. Sust. Energ. Rev. 58 (2016) 1293-1307.

13. C.Y. Yang, R. Li, C. Cui, S.P. Liu, Q. Qiu, Y.G. Ding, Y.X. Wu, B. Zhang, Green Chem. 18 (2016) 3684-3699.

14. H. Shafaghat, P.S. Rezaei, W.M.A.W. Daud, RSC Advances 5 (2015) 103999104042.

15. P. Platanitis, G.D. Panagiotou, K. Bourikas, Ch. Kordulis, A. Lycourghiotis, The Open Catalysis Journal 7 (2014) 18-25.

16. Z. He, X. Wang, Catalysis for Sustainable Energy 1 (2012) 28-52 https://doi.org/10.2478/cse-2012-0004.

17. E. Laurent, D. Sci. Thesis, Universite' Catholique de Louvain, Louvain-la-Neuve, Belgium, 1993.

18. D.C. Elliott, T.R. Hart, Energy Fuels 23 (2009) 631-637.

19. S. Tang, L. Ji, J. Lin, H.C. Zeng, K.L. Tan, K. Li, J. Catal. 194 (2000) 424-430.

20. Y. Zhang, G. Xiong, S. Sheng, W. Yang, Catal. Today 63 (2000) 517-522.

21. J.-H. Kim, D.J. Suh, T.-J. Park, K.-L. Kim, Appl. Catal. A 197 (2000) 191-200.

22. L. Qu, W. Zhang, P.J. Kooyman, R. Prins, J. Catal. 215 (2003) 7-13.

23. T. G. Harvey, T. W. Matheson, J. Chem. Soc., Chem. Commun., 1985, 188-189.

24. E. Peeters, M. Cattenot, C. Geantet, M. Breysse, J.L. Zotin, Catal. Today 133-135 (2008) 299-304.

25. Q. Liu, F. Gu, X. Lu, Y. Liu, H. Li, Z. Zhong, G. Xu, F. Su, Appl. Catal. A 488 (2014) 37-47.

26. P.G. Savva, K. Goundani, J. Vakros, K. Bourikas, C. Fountzoula, D. Vattis, A. Lycourghiotis, C. Kordulis, Appl. Catal. B 79 (2008) 199-207. 
27. C. Kordulis, K. Bourikas, M. Gousi, E. Kordouli, A. Lycourghiotis, Appl. Catal. B 181 (2016) 156-196.

28. M. Wang, X. Zhang, H. Li, J. Lu, M. Liu, F. Wang, ACS Catal. 8 (2018) 16141620.

29. M. N. Gatti, F. Pompeo, G. F. Santori, N. N. Nichio, Catal. Today 296 (2017) 2634.

30. C. Wang, J. Luo, V. Liao, J. D. Lee, T. M. Onn, C. B. Murray, R. J. Gorte, Catal. Today 302 (2018) 73-79.

31. H. Lee, Y.-M. Kim, K. B. Jung, J. Jae, S.-C. Jung, J.-K. Jeon, Y.-K. Park, J. Cleaner Prod. 174 (2018) 763-770.

32. J. Liu, C. Li, F. Wang, S. He, H. Chen, Y. Zhao, M. Wei, D.G. Evans, X. Duan, Catal. Sci. Technol. 3 (2013) 2627-2633.

33. J.A. Lercher, J.H. Bitter, W. Hally, W. Niessen, K. Seshan, Stud. Surf. Sci. Catal. 101 (1996) 463-472.

34. S. Encheandia, P.L. Arias, V.L. Barrio, B. Pawelec, J.L.G. Fierro, Appl. Catal. B: Environ. 101 (2010) 1-12.

35. S.S. Maluf, E.M. Assaf, Fuel 88 (2009) 1547-1553.

36. E. Kordouli, L. Sygellou, C. Kordulis, K. Bourikas, A. Lycourghiotis, App. Catal. B 209 (2017) 12-22.

37. E. Kordouli, B. Pawelec, K. Bourikas, C. Kordulis, J.L.G. Fierro, A. Lycourghiotis, Appl. Catal. B: Environ. 229 (2018) 139-154.

38. M. Gousi, C. Andriopoulou, K. Bourikas, S. Ladas, M. Sotiriou, C. Kordulis, A. Lycourghiotis, Appl. Catal. A 536 (2017) 45-66.

39. J. Sun, S. Chen, M.J. Rood and M. Rostam-Abadi, Energy Fuels 12 (1998) 10711077.

40. E.P. Barrett, L.G. Joyner, P.H. Halenda, J. Am. Chem. Soc. 73 (1951) 373-380.

41. C.D. Wagner, W.M. Riggs, L.E. Davis, J.F. Moulder, G.E. Muilenberg, Perkin Elmer Corp. 1979.

42. A. Tribalis, G.D. Panagiotou, K. Bourikas, L. Sygellou, S. Kennou, S. Ladas, A. Lycourghiotis, C. Kordulis, Catalysts 6 (2016) \#11.

43. Q. Liu, J. Gao, F. Gu, X. Lu, Y. Liu, H. Li, Z. Zhong, B. Liu, G. Xu, F. Su, J. Catal. 326 (2015) 127-138.

44. E. Kraleva, M.-M. Pohl, A. Jurgensen, H. Ehrich, Appl. Catal. B 179 (2015) 509-520.

45. S. Damyanova, B. Pawelec, K. Arishtirova, J.L.G. Fierro, Int. J. Hydrogen Energy 37 (2012) 15966-15975.

46. M. Zaungouei, A.Z. Moghaddam, M. Arasteh, Chem. Eng. Res. Bull. 14 (2010) 97102.

47. S.R. Kirumakki, B. G. Shpeizer, G. V. Sagar, K.V.R. Chary, A. Clearfield, J. Catal. 242 (2006) 319-331.

48. A. Guevara-Lara, R. Bacaud, M. Vrinat, Appl. Catal. A 328 (2007) 99-108.

49. G. Deo, I.E. Wachs, J. Phys. Chem. 95 (1991) 5889-5895.

50. N. Spanos, L. Vordonis, C. Kordulis and A. Lycourghiotis, J. Catal. 124 (1990) 301-314. 
51. S Dzwigaj, C Louis, M Breysse, M Cattenot, V Bellière, C Geantet, M Vrinat, $P$ Blanchard, E Payen, S Inoue, H Kudo, Y Yoshimura, Appl. Catal. B: Environ. 41 (2003) 181-191.

52. E.L. Lee, I.E. Wachs, J. Phys. Chem. C 111 (2007) 1410-14425.

53. J. Gao, Y. Zheng, J.-M. Jehng, I.E. Wachs, S.G. Podkolzin, Science 348(6235) (2015) 686-690.

54. S. Chempath, Y. Zhang, A.T. Bell, J. Phys. Chem. C 111 (2007) 1291-1298.

55. Z. Liu, S. Zhang, J. Li, L. Ma, Appl. Catal. B: Environ. 144 (2014) 90-95.

56. J. Fan, P. Ning, Z. Song, X. Liu, L. Wang, J. Wang, H. Wang, K. Long, Q. Zhang, Chem. Eng. J. 334 (2018) 855-863.

57. D. Wang, Y. Peng, S. Xiong, B. Li, L. Gan, C. Lu, J. Chen, Y. Ma, J. Li, Appl. Catal. B: Environ. 221 (2018) 556-564.

58. NIST Standard Reference Database Number 69, http://webbook.nist.gov/chemistry/.

59. M. Wallin, H. Grönbeck, A. Lloyd Spetz, M. Skoglundh, Appl. Surf. Sci. 235 (2004) 487-500.

60. F. Liu, S. Xu, L. Cao, Y. Chi, T. Zhang, D. Xue, J. Phys. Chem. C 111 (2007) 73967402.

61. K.V.R. Chary, K.R. Reddy, G. Kishan, J.W. Niemantsverdriet, G. Mestl, J. Catal. 226 (2004) 283-291.

62. G. Poncelet, M.A. Centeno, R. Molina, Appl. Catal. A: Gen. 288 (2005) 232-242.

63. L. Daza, B. Pawelec, J.A. Anderson, J.L.G. Fierro, Appl. Catal. A: Gen. 87 (1992) 145-156.

64. D.G. Blackmond, E.I. Ko, J. Catal. 96 (1985) 210-221.

65. M. Hair, Marcel Dekker Inc., New York, 1967.

66. R. Navarro, B. Pawelec, J.L.G. Fierro, P.T. Vasudevan, J.F. Cambra, P.L. Arias, Appl. Catal. A: Gen. 137 (1996) 269-286.

67. J.B. Peri, J. Catal. 86 (1984) 84-94.

68. B. Pawelec, L. Daza, J.L.G. Fierro, J.A. Anderson, Appl. Catal. A; Gen. 145 (1996) 307-322.

69. R. Miao, X. Yu, W. Zeng, Mater. Lett. 173 (2016) 107-110.

70. R. Miao, W. Zeng, Q. Gao, Appl. Surf. Sci. 384 (2016) 304-310.

71. J. Wang, W. Zeng, Z. Wang, Ceram. Int. 42 (2016) 4567-4573.

72. X. Liu, X. Wang, X. Yuan, W. Dong, F. Huang, J. Mater. Chem. A 4 (2016) 167172.

73. V.A. Yakovlev, S.A. Khromova, O.V. Sherstyuk, V.O. Dundich, D.Yu. Ermakov, V.M. Novopashina, M.Yu. Lebedev, O. Bulavchenko, V.N. Parmon, Catal. Today 144 (2009) 362-366.

74. A. Gutiérrez, J.M. Arandes, P. Castaño, A.T. Aguayo, J. Bilbao, Energy Fuels, 25 (2011) 3389-3399.

75. G. de la Puente, A. Gil, J.J. Pis, P. Grange, Langmuir 15 (1999) 5800-5806.

76. L.J. Hoyos, M. Primet, H. Praliaud, J. Chem. Soc. Faraday Trans., 88(1) (1992) 113-119. 
77. C.L. Pieck, R.J. Verderone, E.J. Jablonski, J.M. Parera, Appl. Catal. 55 (1989) 110.

78. J.H. Sinfelt, G.H. Via, F.W. Lytle, Catal. Rev.-Sci. Eng., 26 (1984) 81-140.

79. D. Kubicka, J. Horácek, Appl. Catal. A: Gen. 394 (2011) 9-17.

80. O.U. Valdés-Martínez, V.A. Suárez-Toriello, J.A. de losReyes, B. Pawelec, J.L.G. Fierro, Catal. Today 296 (2017) 219-227.

81. B. Seemala, C.M. Cai, R. Kumar, C. E. Wyman, P. Christopher, ACS Sustain Chem Eng. 6 (2018) 2152-2161.

82. V.O.O. Goncalves, P. M. de Souza, T. Cabioch, V. Teixeira da Silva, F. B. Noronha, F. Richard, Appl. Catal. B: Environ. 219 (2017) 619-628.

83. M.S. Jang, T.N. Phan, I.S. Chung, I.-G. Lee, Y.-K. Park, C.H. Ko, Res Chem Intermed 44 (2018) 3723-3735.

84. T.M. Sankaranarayanan, M. Kreider, A. Berenguer, S. Gutiérrez-Rubio, I. Moreno, P. Pizarro, J.M. Coronado, D.P. Serrano, Fuel 214 (2018) 187-195.

85. H. Taghvaei, M. R. Rahimpour, P. Bruggeman. RSC Adv. 7 (2017) 30990-30998.

86. H. Jahromi, F.A. Agblevor, Appl. Catal. A, Gen. 558 (2018) 109-121.

87. X. Xu, E. Jiang, Z. Li, Y. Sun, Fuel 221 (2018) 440-446.

88. H. Lee, Y.-M. Kim, K. B. Jung, J. Jae, S.-C. Jung, J.-Ki Jeon, Y.-K. Park, J. Clean. Prod. 174 (2018) 763-770.

89. D.P. Gamliel, B. P. Baillie, E. Augustine, J. Hall, G.M. Bollas, J.A. Valla, Microporous Mesoporous Mater. 261 (2018) 18-28.

90. O.O. Ayodele, F. A. Dawodu, D. Yan, J. Xin, S. Zhang, Fuel 221 (2018) 311-319.

91. S. Jin, W. Guan, C.-W. Tsang, D. Y. S. Yan, C.-Y. Chan, C. Liang, Catal. Lett. 147 (2017) 2215-2224.

92. V.O.O. Goncalves, C. Ciotonea, S. Arrii-Clacens, N. Guignard, C. Roudaut, J. Rousseau, J.-M. Clacens, S. Royer, F. Richard, Appl. Catal. B: Environ. 214 (2017) 57-66.

93. C. Ranga, R. Lødeng, V.I. Alexiadis, T. Rajkhowa, H. Bjørkan, S. Chytil, I.H. Svenum, J. Walmsley, C. Detavernier, H. Poelman, P. Van Der Voort, J. W. Thybaut, Chem. Engin. J. 335 (2018) 120-132.

94. T. Prasomsri, M. Shetty, K. Murugappan, Y. Roman-Leshkov, Energy Environ. Sci., 7 (2014) 2660-2669.

95. M. Shetty, K. Murugappan, T. Prasomsri, W.H. Green, Y. Román-Leshkov, J. Catal. 331 (2015) 86-97.

96. T.L.R. Hewer, A. G.F. Souza, K. T.C. Roseno, P. F. Moreira ,R. Bonfim, R.M.B. Alves, M. Schmal, Renew. Energ. 119 (2018) 615-624.

97. T. He, X. Liu, Y. Ge, D. Han, J. Li, Z. Wang, J. Wu, Catal. Commun. 102 (2017) $127-130$. 